Article

\title{
Effects of Extensive Green Roofs on Energy Performance of School Buildings in Four North American Climates
}

\author{
Milad Mahmoodzadeh ${ }^{1}$, Phalguni Mukhopadhyaya ${ }^{1} \mathbb{D}$ and Caterina Valeo ${ }^{2, * \mathbb{D}}$ \\ 1 Civil Engineering, University of Victoria, Victoria, BC V8W 2Y2, Canada; \\ miladmahmoodzadeh@uvic.ca (M.M.); phalguni@uvic.ca (P.M.) \\ 2 Mechanical Engineering, University of Victoria, Victoria, BC V8W 2Y2, Canada \\ * Correspondence: valeo@uvic.ca; Tel.: +1-250-721-8623
}

Received: 18 September 2019; Accepted: 11 December 2019; Published: 18 December 2019

\begin{abstract}
A comprehensive parametric analysis was conducted to evaluate the influence of the green roof design parameters on the thermal or energy performance of a secondary school building in four distinctively different climate zones in North America (i.e., Toronto, ON, Canada; Vancouver, BC, Canada; Las Vegas, NV, USA and Miami, FL, USA). Soil moisture content, soil thermal properties, leaf area index, plant height, leaf albedo, thermal insulation thickness and soil thickness were used as design variables. Optimal parameters of green roofs were found to be functionally related to meteorological conditions in each city. In terms of energy savings, the results showed that the light-weight substrate had better thermal performance for the uninsulated green roof. Additionally, the recommended soil thickness and leaf area index for all four cities were $15 \mathrm{~cm}$ and 5 respectively. The optimal plant height for the cooling dominated climates is $30 \mathrm{~cm}$ and for the heating dominated cities is $10 \mathrm{~cm}$. The plant albedo had the least impact on the energy consumption while it was effective in mitigating the heat island effect. Finally, unlike the cooling load, which was largely influenced by the substrate and vegetation, the heating load was considerably affected by the thermal insulation instead of green roof design parameters.
\end{abstract}

Keywords: green roof; energy performance; low impact development; heat island effect

\section{Introduction}

In recent years, due to a growing population and rapid urbanization, the demand for energy and water has increased significantly [1]. In 2010, buildings contributed to $32 \%$ of total energy used in the world and one-third of greenhouse gases [2,3]. Hence, buildings can play a significant role in limiting global warming and reducing climate change impacts. Green or vegetated roofs are regarded as an appropriate solution for the reduction of heating and cooling loads in buildings. Vegetated roofs mitigate the heat flux through the roof by shading the roof surface with plants, evapotranspiration of the plants, and the additional thermal insulation and mass, which are caused by the growing media [4]. There is a wide range of investigations that show the other advantages of green roofs such as reduction of stormwater runoff [5-8] as a Low Impact Development (LID) option, urban heat island effects [9-11], sound insulation [6,12], enhancement of the life span of a roof [13], creation habitats for species, and improving air quality by absorbing $\mathrm{CO}_{2}$ and producing $\mathrm{O}_{2}$ [14-20]. Due to the aforementioned benefits of green roofs, many local authorities in different countries have implemented the policy for using green roofs in new buildings. For instance, in Toronto, Canada, new buildings with a surface area of more than $2000 \mathrm{~m}^{2}$ should have between $20 \%$ and $60 \%$ vegetation coverage of the roof area. In Tokyo, Japan newly constructed buildings must have at least $20 \%$ vegetated roof; in Portland, USA, all new 
buildings should have at least $70 \%$ green roof coverage of their rooftops; and in Basel, Switzerland, the roofs of new or retrofitted buildings need to be covered with at least $15 \%$ vegetation [1]. It is important to note that the performance of green roofs depends on different design variables such as growing media, composition and thickness, slope of roof, type of vegetation, and hydrologic variables such as rainfall and antecedent dry weather periods (ADWP). Additionally, the design variables will be different in different climate zones. Hence, these are the main obstacles for policymakers, designers and stormwater managers for implementing a green roof system in different climates [21].

Although the environmental advantages of green roofs is the main goal of local authorities in most cities, the thermal benefits of green roofs are of great importance and should be considered by the constructors and engineers for designing this type of roof.

A wide range of experimental and numerical studies to evaluate the effect of a green roof on the energy consumption of buildings in different climates have been conducted. For instance, different types of green vegetation such as sedum, grass and graminaceous plants have been used to analyze their impacts on the energy performance of a one-story office building in European climates. The results of energy modeling indicated that the cooling load consumption could be reduced between 1 to $11 \%$ in warm climates and up to $7 \%$ in cold climates [17]. Another study, evaluating the energy performance of an extensive green roof with Origanum heraclioticum plants for a supermarket in Athens, Greece showed that the cooling and heating loads were reduced by $18.7 \%$ and $11.4 \%$, respectively [22]. Furthermore, different plant species with different height results in the literature are not consistent with one green roof study showing no effective energy savings of a mock up building in Pennsylvania, USA [23]. Another study in the Mediterranean climate in Italy compared the energy performance of a conventional roof with an extensive green roof covered with sedum plants, in which the green roof had a $100 \%$ reduction in thermal energy entering the roof in the summer and 30 to $37 \%$ of heat loss during the winter [24]. Jaffal et al. [4] conducted a study on the effect of a green roof on the energy performance of a single-family house with insulate roof in three different climates. The results of a simulation showed that heating increased by $8 \%$ in a Mediterranean climate while it did not have an effect on the heating load of the temperature climate. However, in cold climates (Stockholm), due to the insulation effect of a green roof, the heating load decreased by $8 \%$. The results of energy modeling of a two-story nursery building with conditioned space showed that the cooling load reduced by $6-33 \%$. The heating load increased by 3-9\% for the insulated roof; however, for the uninsulated roof there was a reduction in heating demand [25].

To properly evaluate the influence of green roofs on the building energy performance, architects and engineers should evaluate the importance of design variables, external conditions and building type. The main design parameters that influence the thermal performance of green roofs are plant coverage and growing media. The main characteristics of plants that have to be considered in the design are leaf area index (LAI), plant height, stomatal resistance, leaf albedo and emissivity. Similarly, the growing media design characteristics are thickness, thermal properties and moisture content.

Several studies have analyzed the energy performance of green roofs by conducting a parametric analysis of one or more of these design variables. For instance, the energy consumption varied from $1 \%$ to $15 \%$ for a five-story building in Singapore by changing the soil thickness, moisture content of the substrate and plant type [26]. A parametric study in a Mediterranean climate showed that the LAI was the most influential parameter in reducing the cooling demand through evapotranspiration [27]. Furthermore, the LAI and substrate thermal properties were the most effective parameters in reducing cooling and heating loads for a supermarket in a semi-arid climate [28]. Sailor et al. [29] investigated the effect of climate, LAI and soil thickness in four USA cities including Houston, New York, Portland and Phoenix. The results reported that the green roof with deeper soil thickness could reduce the heating demand in cold cities. However, the LAI saved energy for the cooling dominated cities by using evapotranspiration and surface shading of plants. The investigation in Midwestern USA, for a city with hot and humid summers and cold and snowy winters, concluded that a green roof reduces the heat flux in summer and winter by $16 \%$ and $13 \%$, respectively [30]. Ascione et al. [17] used 
the EnergyPlus®software to compare the effect of leaf index area on green roof performance in two different cities in Tenerife, Spain and Oslo, Norway. The investigation found that by increasing the leaf index area from 0.8 to 5 the energy savings for the cooling load in Tenerife increased from $1 \%$ to $11 \%$, and the heating energy savings in Oslo was $5 \%$ with LAI $=5$, and the savings was $6 \%$ with $\mathrm{LAI}=0.8$ (because of lower solar absorption). In another study [31] using EnergyPlus@in Portugal, the thermal performance of three types of green roofs (extensive, semi-intensive and intensive) with two conventional roofs with different surface color (black and white) was studied. Additionally, the effects of plant height and leaf area index were evaluated. The results showed that the semi-intensive and intensive green roofs with moderate thermal insulation had better energy saving compared to the black and white roofs. However, the extensive green roof had good performance in buildings without insulation (old buildings). In addition, the leaf area index and plant height improved the energy savings in cooling seasons considerably and the soil depth had a major effect in heating seasons. Design Builder@was used in a numerical simulation [32] to study the effects of leaf area index, soil depth and insulation thickness in including warm-dry, warm-coastal and cool-humid climates. The results demonstrated that the insulation thickness had a positive effect in reducing the energy use intensity (EUI) effect in Phoenix while it was reversed for Chicago. The EUI in Los Angeles was affected by the leaf area index. Gomes et al. [33] conducted a parametric analysis to analyze the impact of design parameters such as plant height and LAI on cooling and heating loads in a Mediterranean climate. The results showed that the cooling load increased up to $365 \%$ with a LAI of 1 compared to the LAI of 5 . However, the heating load was influenced mostly by soil thickness, whereas heating load increased by $140 \%$ with a reduction of soil thickness from 1 to $0.1 \mathrm{~m}$. Furthermore, with lower plant height $(0.05 \mathrm{~m})$ and LAI of 1 heating load reduced $23 \%$ and $18 \%$, respectively.

The aforementioned studies were mostly for warm and Mediterranean climates and only a few research studies were conducted on the energy savings of a green roof in cold climates. The effects of snow depth and vegetation types were evaluated in Saint Mary's University, which is located in Halifax, Canada [34]. The research found that the green roof had lower heat loss when compared to the conventional roof. However, there was no difference in heat loss between the green roof and the conventional roof when the growing media was frozen or snow covered the roof surfaces. In addition, the variety of vegetation affected the depth of snow, duration of snow coverage and substrate temperatures. The effect of phase change in the green roof growing media was recently investigated during the winter at Purdue University [35]. The analysis showed that the green roof reduced heat loss up to $17.9 \%$ during the entire winter in comparison with the conventional roof. Additionally, during the phase change period (liquid to ice) the growing media stored a lot of energy and as a result, the growing media had a higher temperature. The heat loss was reduced during the phase change period in the winter by $19 \%$ while the heat loss reductions during the period without phase changes (the water was completely liquid or ice) were between $15-17 \%$.

In spite of government funding for implementing the green roofs on buildings in Canada, few studies have considered the energy benefits of a green roof in this country, and these were mostly experimental. For example, results of a study in Toronto [36] for a single family and low-rise commercial buildings concluded that $\$ 11$ Million of energy can be saved by using a combination of cool roofs and shaded trees. The study also reported that the urban heat island (UHI) effect of green roofs could reduce the electricity demand for cooling systems during the summer. It noted that a $0.6{ }^{\circ} \mathrm{C}$ increase in ambient temperature would increase the cooling peak demand from $1.5 \%$ to $2 \%$. The National Research Council of Canada (NRCC) studied, analyzed and compared a typical extensive green roof with a conventional roof in Ottawa [37]. The results showed that the green roof reduced the heat flow through the roof in summer considerably more than in winter. The energy consumption for space conditioning was $75 \%$ lower than the reference roof. Additionally, during the days without snow, the green roof was slightly better than the conventional roof because of the growing media insulation effect. However, when the growing media was frozen, the thermal conductivity increased and the insulation effect was diminished. Therefore, both roofs had similar heat loss under the snow coverage. 
Another experimental study by NRCC [38] analyzed two different green roofs with a reference roof in Toronto. The differences between green roofs were in the thickness and color of the growing media. The analysis illustrated that both green roofs reduced the heat gain and heat loss through the roof as well as peak load, significantly more than the reference roof. The green roofs reduced the heat gain during the summer by $70-90 \%$ and heat losses during the winter by $10-30 \%$.

The British Columbia Institute of Technology (BCIT) conducted an experimental study to compare the energy performance of two green roofs with different growing media thicknesses with a reference roof on the west coast of British Columbia [39]. The study concluded that the green roof with thinner growing media had a smaller heat loss compared to the thicker growing media. Similar to the previous studies, the results showed that green roofs had a better performance compared to the reference roof and they saved energy through the roof during summer and spring from 83 to $85 \%$, during the winter and fall from 40 to $44 \%$ and overall, a 66\% reduction of annual energy consumption. A recent study for an office building in the Ryerson University in Toronto [40] analyzed the effects of LAI and soil thickness on energy consumption. The results showed that the growing media thickness was more effective in the reduction of energy. Additionally, the heating demand was reduced by $3 \%$ compared to the conventional roof.

One of the most important parameters that influences the effectiveness of a green roof is the thermal insulation of the roof: a green roof without thermal insulation reduces the cooling load considerably more than in the Mediterranean climate [27]. Another study in this climate demonstrated that the insulated green roof consumed more energy than the conventional roof [31]. A single-family residential building in the Oceanic climate of LaRochelle, France proved that uninsulated and insulated green roofs saved energy $48 \%$ and $10 \%$ more than the conventional roof, respectively [4]. Similarly, the energy reductions for well-insulated, moderately insulated and uninsulated green roofs for an office building in the Mediterranean climate of Athens (Greece) were 2\%, 7\% and 48\%, respectively [41]. An experimental and simulation study in four U.S. climates concluded that the green roof with insulation was less effective in reducing energy consumption [42]. Pablo in his study proved that the green roof without insulation could have appropriate performance in the summer but not in the winter, as a lower heat transfer coefficient was needed for reducing the heating load [43].

Previous investigations mainly focused on the energy saving of a green roof in commercial or residential buildings and a couple of studies were conducted on other types of buildings such as retail stores or supermarkets [1,28]. School buildings in North America tend to be very large, and are designed with varying functionality (such as pools, gymnasiums and classrooms) and have significant energy consumption. However, the effect of vegetated roofs on the energy performance of this type of infrastructure has not been taken into consideration. The National Center for Education Studies reported that the number of buildings allocated for education in the USA was more than 100,000 [44]. It is notable that for each of the aforementioned schools, a considerable amount of energy was consumed to provide electricity for the students and teachers. According to a report by Xcel Energy [44], almost \$6 million per year is spent for the required energy in schools. According to a survey by the U.S. Department of Energy in 2013, school buildings consumed 8\% of energy among commercial and institutional buildings [45]. Likewise, in Canada, schools are regarded as one of the major consumers of energy with an energy intensity of $0.88 \mathrm{GJ} / \mathrm{m}^{2}$. According to Natural Resources Canada (NRCan), the average annual energy consumption of schools in Canada is $472 \mathrm{kWh} / \mathrm{m}^{2}$ [46]. School buildings in Ontario make up a 30\% proportion of energy consumption in the public sector [47]. Another study by NRCan showed that after office and food storage buildings, as well as schools are the third largest energy consumer in Canada with 8\% energy consumption among commercial and institutional buildings [48].

Despite the necessity of energy savings in this sector in North America, previous research has mostly focused on specific locations and buildings when analyzing the effectiveness of green roofs on energy consumption. Furthermore, there has been no comprehensive study in this region to analyze the influence of green roof design parameters such as LAI, plant height, plant albedo, soil thickness, 
thermal insulation thickness and soil thermal properties, on the use of energy in buildings. In this research a parametric analysis focusing on secondary school buildings in different climates of North America was conducted in order to provide insight into the influence of these important design parameters on school building energy budgets. The selected climates included the cool-humid climate of Vancouver, Canada, the cold-continental climate of Toronto, Canada, the hot-dry climate of Las Vegas, USA and the hot-humid climate of Miami, USA.

\section{Methodology}

The methodology employed in this research involved simulating the energy balance of school buildings with two different green roof designs in the four climates. A parametric analysis of design parameters was conducted within this simulation in order to determine their influence on energy balance. This study focused on the influence of substrate (the vegetation growing media) thermal properties and moisture content on the energy performance of the green roof assembly by considering two different substrates: (1) heavy-weight and (2) light-weight based soil.

\subsection{Simulation Tool}

EnergyPlus, which is one of the most well-known energy modeling software available, was used in this study. Developed by the U.S. Department of Energy (DOE), it combines two energy modeling programs BLAST and DOE-2, which were developed by the U.S. Department of Defense and the DOE, respectively [49]. EnergyPlus calculates the required energy for heating, cooling, lighting, and ventilation as well as water heating in buildings, by considering all outdoor and indoor parameters including geographical location, outside temperature, solar radiation intensity and direction, wind speed and direction, glazing shading and radiation characteristics, which were provided in EnergyPlus Weather (EPW) format file, along with generated heat by internal loads such as occupant density and activities, lightening and miscellaneous equipment, infiltration, etc. The heat flux through the building envelopes was calculated based on the BLAST conduction transfer function (CTF) [49].

EnergyPlus 8.8 can model green roofs. This study used the green roof module developed by Portland State University, which was introduced in April 2007 and implemented in EnergyPlus [50]. The green roof model in EnergyPlus 8.8 allows the user to implement the green roof as an outer layer of roof assembly. The user can also vary different green roof design parameters such as growing media thickness and thermal properties, plant canopy density, plant height, stomatal resistance, and soil moisture conditions (including irrigation and precipitation) [49]. The energy balance in green roof assemblies is determined by balancing solar radiation (similar to that of a conventional roofing system). The solar radiation is balanced by the sensible and latent heat flux (evapotranspiration) through the soil and plants, conductive heat transfers through the soil, and long-wave radiation to and from the soil and plant surfaces. It should be noted that the rate of evapotranspiration is influenced by external conditions such as relative humidity, solar radiation, ambient air temperature, wind speed and substrate moisture content, which was considered when analyzing the results.

\subsection{Building Model and Green Roof Parameters}

EnergyPlus has a number of prototype buildings according to ANSI/ASHRAE/IES Standard 90.1-2013, and in this research the "secondary school" building was selected [51,52]. The building geometry was created using SketchUp. SketchUp has an OpenStudio plug-in that allows SketchUp building geometry to be used by EnergyPlus. The geometry of the building is shown in Figure 1. The school building consisted of two floors, $19,592 \mathrm{~m}^{2}$ of conditioned space, $11,902 \mathrm{~m}^{2}$ of roof area, a window to wall ratio of $33 \%$ and a total of 46 thermal zones, which were ventilated with a VAV system. The building had constant thermostat set points for both heating $\left(21^{\circ} \mathrm{C}\right)$ and cooling $\left(24^{\circ} \mathrm{C}\right)$, an occupancy of 0.3 people $/ \mathrm{m}^{2}$, and a lighting intensity of $12.5 \mathrm{~W} / \mathrm{m}^{2}$. A metal roof assembly with an albedo of 0.2 was considered for the building. The characteristics of the materials used in the roof structure were defined based on the EnergyPlus software library, as shown in Table 1. Schematics of 
the roof structure and green roof system are shown in Figure 2. The U-value of the walls and windows were $0.5 \mathrm{~W} / \mathrm{m}^{2} \mathrm{~K}$ and $3.2 \mathrm{~W} / \mathrm{m}^{2} \mathrm{~K}$, respectively.

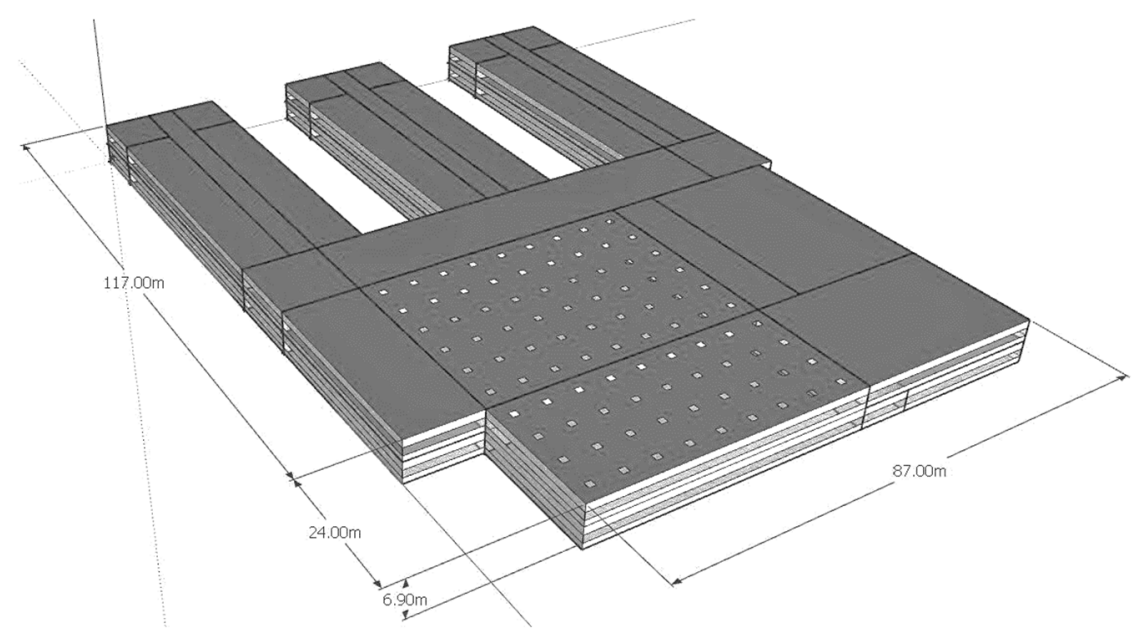

Figure 1. Secondary school building geometry.

Outdoor

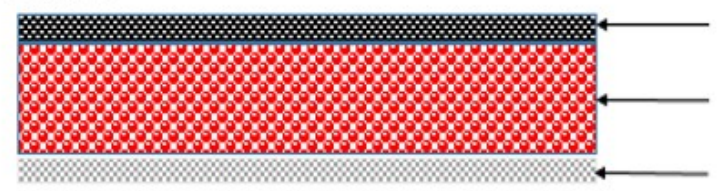

Roof membrane $(0.0095 \mathrm{~m})$

Thermal insulation $(0.05 \mathrm{~m})$

Indoor

Metal decking $\quad(0.002 \mathrm{~m})$

(a)

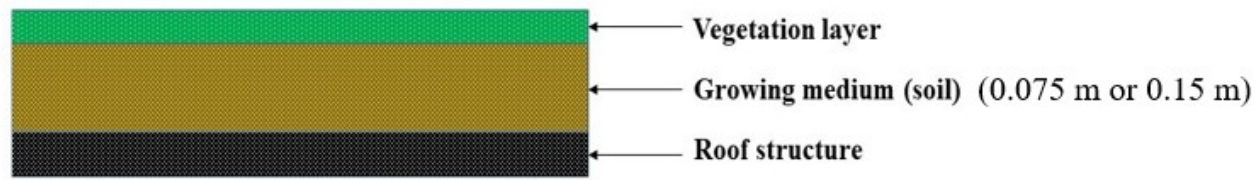

(b)

Figure 2. (a) Schematic of roof structure; (b) schematic of green roof system.

Table 1. Thickness and thermal properties of the roof materials layer [53].

\begin{tabular}{ccccc}
\hline Material & $\begin{array}{c}\text { Thickness } \\
(\mathbf{m})\end{array}$ & $\begin{array}{c}\text { Density } \\
\mathbf{( k g / \mathbf { m } ^ { 3 } )}\end{array}$ & $\begin{array}{c}\text { Thermal Conductivity } \\
\mathbf{( W / m} \cdot \mathbf{K})\end{array}$ & $\begin{array}{c}\text { Specific Heat } \\
\mathbf{J} / \mathbf{k g} \cdot \mathbf{K})\end{array}$ \\
\hline Roof membrane & 0.0095 & 1121 & 0.16 & 1460 \\
Thermal insulation (polyurethane) & 0.05 & 40 & 0.04 & 1600 \\
Metal decking & 0.002 & 7680 & 45 & 418 \\
\hline
\end{tabular}

To design and optimize the thermal performance of building envelopes, such as walls and roofs, the climatological conditions of buildings should be considered by designers. The heating degree days (HDD) and cooling degree days (CDD) are measures of heating and cooling loads in buildings that are often used. ASHRAE climate zones is divided based on two parameters: temperature and moisture. The temperature is shown with a number ranges from 1 (hottest) to 8 (coldest), and moisture is demonstrated with a letter including A (moist), B (dry) and C (Marine). Hence, to study the effect of different climates on the energy performance of a green roof, the same building was considered in four different climates consisting of hot-dry, hot-humid, cool-humid and humid-continental. Here, simulations were performed for each city using third typical meteorological year (TMY3) weather files 
for U.S. cities [54] and Canadian Weather for Energy Calculations (CWEC) weather files for Canadian cities [55]. The climatic information for the four selected cities is summarized in Table 2.

Table 2. Summary climate data for the four cities modeled.

\begin{tabular}{cccccc}
\hline City & $\begin{array}{c}\text { Annual HDD } \\
\text { Base } \mathbf{1 8} \mathbf{\circ}^{\circ} \mathbf{C}\end{array}$ & $\begin{array}{c}\text { Annual CDD } \\
\text { Base } \mathbf{1 0}{ }^{\circ} \mathbf{C}\end{array}$ & $\begin{array}{c}\text { Summer } \\
\text { Conditions }\end{array}$ & $\begin{array}{c}\text { Winter } \\
\text { Conditions }\end{array}$ & $\begin{array}{c}\text { ASHRAE } \\
\text { Climate Zone * }\end{array}$ \\
\hline Toronto & 3956 & 1316 & Humid, Warm & Cold & 6A \\
Vancouver & 2932 & 951 & Moderate & Mild & $5 \mathrm{C}$ \\
Las Vegas & 1169 & 3908 & Dry, Hot & Mild & 2B \\
Miami & 72 & 5447 & Humid, Hot & Moderate & $1 \mathrm{~A}$ \\
\hline
\end{tabular}

${ }^{*}$ A indicates moist, $\mathrm{B}$ indicates dry and $\mathrm{C}$ indicates marine moisture conditions.

In order to understand the impacts of different green roof parameters on the energy performance of buildings, with the exception of the roof assembly, all building characteristics such as building envelopes, internal loads and schedules remained unchanged. For comparison, the thermal responses of two conventional roofs with (R-7) and without insulation were also studied. An uninsulated extensive green roof with shallow growing media and an adequate structure for building retrofitting was considered in this study. Additionally, green roof irrigation was not considered in this investigation. The vegetation types, which are used in green roofs must be adapted to harsh environmental conditions on the roof. Vegetation type could change the hydrologic behavior of green roofs in terms of interception, uptake, transpiration and storage of water [21]. For instance, grass has better performance than sedum in storm water retention while sedum is one of the most compatible plants used in extensive green roofs [21]. Hence, in selecting the vegetation type, the hydrologic behavior of the green roof along with its effect on energy performance had to be considered. Based on plant type, the design parameters such as LAI, plant height and leaf albedo varied. For instance, the LAI of sedum typically ranges from 2 to 4 [56]. Feng et al. [57] reported a LAI of 4.6 for Sedum lineare. Furthermore, [17] used sedum short and tall cut with LAI of 0.8 and 3, respectively. Graminaceous short cut and tall cut has a LAI of 2.5 and 5, respectively [17]. Gagliano et al. [58] used a combination of different plants such as sedum, mosses, graminaceous or other succulent type plants with a LAI of 5, as the vegetation layer for an extensive green roof. The plant height depends on the type of plant and the type of green roof. For instance, the plant height of sedum sediforme with flowering stems range from 25 to $60 \mathrm{~cm}$ [59]. Sedum short cut and long cut have plants of heights of $10 \mathrm{~cm}$ and $30 \mathrm{~cm}$, respectively [17]. Likewise, different plants have different plant albedo. For example, in [38] plant albedo of different types of sedum were studied where sedum tomentosum and mixed sedum species had a plant albedo of 0.23 and 11, respectively. Additionally, Ascione et al. [17] considered a plant albedo of 0.22 for both short and tall cut sedum for modeling green roofs.

In this study, parameters were selected for an extensive green roof and consisted of different growing media, leaf area index (LAI), plant height, plant albedo, soil thickness and thermal insulation thickness, as shown in Table 3. Substrate and vegetation plant properties were selected based on previous studies [1,17,33,57-59]. Light-weight and heavy-weight substrates were not input parameters in EnergyPlus; however, their properties were considered as inputs in the software. It is important to note that the assumptions that were made for the parametric studies do not represent the realistic conditions of green roofs, such as a constant height or LAI during the year. However, these assumptions were necessary to conduct critical and meaningful parametric analyses. The constant characteristics of the green roof are shown in Table 4.

There are two methods of moisture diffusion for the substrate in EnergyPlus: (1) Simple, and (2) Advanced. The Simple model is the basic model which is based on the moisture diffusion between two layers in the soil. At each time step, the soil properties are updated and based on the moisture content of the layers whereby the moisture distributes at a constant rate from a higher moisture layer to the lower moisture layer. In the Advanced method, moisture diffusion is based on the Schaap 
and van Genuchten model [60]. This model divides the soil into different nodes and then distributes the moisture through the layers. In this study we used the Advanced model because the output it produced in terms of moisture content changed in the soil and was more realistic in comparison to the Simple model [61]. The influence of substrate thermal properties and moisture content on the energy performance of the green roof assembly was studied by using two different substrates: (1) heavy-weight and (2) light-weight based soil [62]. The light-weight growing media had a lower density and thermal conductivity in comparison to the heavy-weight growing media. It should be noted that in EnergyPlus, the thermal properties of soil are constant, as set out in the input file, and do not vary with moisture content [63]. In addition to this, the energy balance of snow and the effect of the freezing of soil on heat transfer are not considered in the current versions of this software [64]. However, it allows users to provide input for precipitation and irrigation schedules, and track the variation of soil moisture content both daily and monthly. The soil properties used in this study were taken from the literature [62]. The materials used in the light-weight soil were $75 \%$ pumice, $10 \%$ compost and 15\% sand. This soil had the highest moisture capacity, lowest thermal conductivity, and lowest density among all soils. The heavy-weight soil consisted of 50\% expanded shale and 50\% sand, and had the highest density and thermal conductivity among the soils. To evaluate the effect of soil moisture content on the energy performance of the green roof, substrate thermal properties were obtained for three levels of moisture content (20\%,60\% and 100\% saturation) as shown in Tables 5 and 6 . These properties were considered as constant inputs for the software while the moisture content of soil varied throughout the year in the software.

Table 3. Design parameters for the parametric analysis.

\begin{tabular}{cc}
\hline Parameter & Value \\
\hline Growing Media & Light-weight and heavy-weight substrates \\
Leaf Area Index (LAI) & $0.1,2,5$ \\
Plant Height (cm) & 10,30 \\
Leaf Reflectivity (Albedo) & $0.11,0.23$ \\
Soil thickness (cm) & $7.5,15$ \\
\hline
\end{tabular}

Table 4. Green roof constant parameter values.

\begin{tabular}{cc}
\hline Parameter & Value \\
\hline Leaf Emissivity & 0.95 \\
Thermal Absorptance & 0.9 \\
Visible Absorptance & 0.75 \\
Minimum Stomatal Resistance & $300(\mathrm{~s} / \mathrm{m})$ \\
Roughness & Medium Rough \\
Saturation Volumetric Moisture Content of the Soil Layer & $0.5\left(\mathrm{~m}^{3} / \mathrm{m}^{3}\right)$ \\
Residual Volumetric Moisture Content of the Soil Layer & $0.01\left(\mathrm{~m}^{3} / \mathrm{m}^{3}\right)$ \\
Initial Volumetric Moisture Content of the Soil Layer & $0.2\left(\mathrm{~m}^{3} / \mathrm{m}^{3}\right)$ \\
Moisture Diffusion Calculation Method & Advanced \\
\hline
\end{tabular}

\section{Results and Discussion}

\subsection{Influence of Soil Type and Moisture Content}

As can be seen in Tables 5 and 6 the thermal conductivity and density increased with the increasing moisture content of the soil. Additionally, as the pores of the soil filled with water, the specific heat capacity of the soil increased because of the fact that water has a higher thermal storage capacity than air. However, by increasing the water content, the soil reflectivity (albedo) reduced significantly as the soil surface was wet and absorbed a higher fraction of solar radiation compared to the dried surface.

Thermal diffusivity, which represents the ability of materials to conduct energy relative to its thermal capacity plays a key role in evaluating the thermal response of materials. The effect of thermal 
diffusivity of soil becomes more important during the summer where the transient heat transfer is more significant because of higher temperature oscillations compared to the winter.

Table 5. Light-weight substrate thermal properties for different levels of moisture [62].

\begin{tabular}{|c|c|c|c|c|c|}
\hline $\begin{array}{l}\text { Saturation } \\
\text { Level }(\%)\end{array}$ & $\begin{array}{l}\text { Density } \\
\left(\mathrm{kg} / \mathrm{m}^{3}\right)\end{array}$ & $\begin{array}{l}\text { Thermal Conductivity } \\
\mathrm{W} /(\mathrm{m} \cdot \mathrm{K})\end{array}$ & $\begin{array}{l}\text { Specific Heat } \\
\mathrm{J} /(\mathrm{kg} \cdot \mathrm{K})\end{array}$ & Albedo & $\begin{array}{l}\text { Thermal Diffusivity } \\
\qquad\left(\mathrm{m}^{2} \mathrm{~s}^{-1}\right)\end{array}$ \\
\hline 20 & 765 & 0.21 & 1284 & 0.27 & $2.12 \times 10^{-7}$ \\
\hline 60 & 870 & 0.31 & 1602 & 0.18 & $2.22 \times 10^{-7}$ \\
\hline 100 & 934 & 0.41 & 1853 & 0.12 & $2.36 \times 10^{-7}$ \\
\hline
\end{tabular}

Table 6. Heavy-weight substrate thermal properties for different levels of moisture [62].

\begin{tabular}{|c|c|c|c|c|c|}
\hline $\begin{array}{l}\text { Saturation } \\
\text { Level }(\%)\end{array}$ & $\begin{array}{l}\text { Density } \\
\left(\mathrm{kg} / \mathrm{m}^{3}\right)\end{array}$ & $\begin{array}{l}\text { Thermal Conductivity } \\
\mathrm{W} /(\mathrm{m} \cdot \mathrm{K})\end{array}$ & $\begin{array}{l}\text { Specific Heat } \\
\mathrm{J} /(\mathrm{kg} \cdot \mathrm{K})\end{array}$ & Albedo & $\begin{array}{l}\text { Thermal Diffusivity } \\
\qquad\left(\mathrm{m}^{2} \mathrm{~s}^{-1}\right)\end{array}$ \\
\hline 20 & 1385 & 0.37 & 936 & 0.09 & $2.85 \times 10^{-7}$ \\
\hline 60 & 1450 & 0.60 & 1035 & 0.04 & $3.91 \times 10^{-7}$ \\
\hline 100 & 1500 & 0.84 & 1095 & 0.02 & $5.10 \times 10^{-7}$ \\
\hline
\end{tabular}

The results in Tables 7 and 8 were for a green roof with a LAI of 2, plant albedo of $0.11,30 \mathrm{~cm}$ plant height and soil thickness of $7.5 \mathrm{~cm}$. The light-weight soil, because of high specific heat capacity and low thermal conductivity, had lower thermal diffusivity compared to the heavy-weight soil. While, it was expected that the heavy-weight soil would have better performance compared to the light soil during the summer months because of its higher thermal capacity, due to the low thermal diffusivity of the light soil, it was found to perform better during the large daily temperature fluctuations between day and night in the summer. This is illustrated in Table 7.

Table 7. Cooling load $\left(\mathrm{kWh} / \mathrm{m}^{2}\right)$ variation with moisture content for insulated (I) and uninsulated (U) roofs in different climates for light-weight (LW) and heavy-weight (HW) soils.

\begin{tabular}{cccccccc}
\hline \multirow{2}{*}{ City } & \multirow{2}{*}{ Insulation } & \multicolumn{2}{c}{$\mathbf{2 0} \%$ Saturated } & \multicolumn{2}{c}{$\mathbf{6 0} \%$ Saturated } & \multicolumn{2}{c}{$\mathbf{1 0 0} \%$ Saturated } \\
\cline { 3 - 8 } & & $\mathbf{L W}$ & $\mathbf{H W}$ & $\mathbf{L W}$ & $\mathbf{H W}$ & $\mathbf{L W}$ & $\mathbf{H W}$ \\
\hline \multirow{2}{*}{ Toronto } & $\mathrm{I}$ & 8.31 & 8.46 & 8.37 & 8.53 & 8.41 & 8.68 \\
& $\mathrm{U}$ & 11.11 & 11.48 & 11.85 & 12.42 & 12.37 & 12.90 \\
\hline \multirow{2}{*}{ Vancouver } & $\mathrm{I}$ & 3.01 & 3.08 & 3.03 & 3.13 & 3.05 & 3.15 \\
& $\mathrm{U}$ & 3.98 & 4.24 & 4.36 & 5.11 & 4.62 & 5.54 \\
\hline \multirow{2}{*}{ Las Vegas } & $\mathrm{I}$ & 41.81 & 45.52 & 42.13 & 42.95 & 42.30 & 43.52 \\
& $\mathrm{U}$ & 57.10 & 58.66 & 57.76 & 62.63 & 58.50 & 66.22 \\
\hline \multirow{2}{*}{ Miami } & $\mathrm{I}$ & 69.12 & 70.16 & 69.64 & 70.42 & 70.44 & 70.64 \\
& $\mathrm{U}$ & 82.93 & 84.24 & 84.81 & 89.37 & 87.22 & 93.70 \\
\hline
\end{tabular}

It was also seen that by increasing the moisture content of the soils, the thermal diffusivity of light soil, unlike heavy-weight soil, remained almost unchanged. However, for the heavy-weight soil, by increasing the moisture content the thermal diffusivity increased. As a result, the cooling load (Table 7) for the uninsulated green roof with the heavy-weight substrate increased considerably more than the light-weight soil. Moreover, as can be seen in Tables 6 and 7, at a moisture level of $20 \%$, the heavy-weight and light-weight soils had similar thermal diffusivity. Therefore, the cooling loads were almost equal to each other in this condition. However, at higher levels of moisture content, the light soil had a better thermal performance compared to the heavy-weight soil.

On the other hand, in winter, thermal conductivity plays a key role in heat transfer through the roof. The thermal conductivity of heavy-weight soil at a higher moisture level was almost twice that of light-weight soil (Table 5). Quite naturally, simulation outputs in Table 8 demonstrate that the heating 
load for the roof with light-weight soil was considerably lower than the same with heavy-weight soil. The importance of thermal conductivity on the heating load is more evident for cities such as Toronto, Vancouver and Las Vegas (cities that experience a cold winter). However, in Miami which has a mild winter, the heating load difference between the light-weight and heavy-weight soil was minimal (Table 8). That is to say that the heating load was not largely affected by the soil type in regions with this climate. Therefore, the uninsulated green roof with light-weight soil had better thermal performance in all four cities.

Table 8. Heating load $\left(\mathrm{kWh} / \mathrm{m}^{2}\right)$ variation with moisture content for insulated and uninsulated roofs in different climates.

\begin{tabular}{cccccccc}
\hline \multirow{2}{*}{ City } & \multirow{2}{*}{ Insulation } & \multicolumn{2}{c}{$\mathbf{2 0} \%$ Saturated } & \multicolumn{2}{c}{$\mathbf{6 0} \%$ Saturated } & \multicolumn{2}{c}{$\mathbf{1 0 0} \%$ Saturated } \\
\cline { 3 - 8 } & & $\mathbf{L W}$ & $\mathbf{H W}$ & $\mathbf{L W}$ & $\mathbf{H W}$ & $\mathbf{L W}$ & $\mathbf{H W}$ \\
\hline \multirow{2}{*}{ Toronto } & $\mathrm{I}$ & 142.60 & 145.23 & 144.23 & 146.46 & 144.90 & 147.00 \\
& $\mathrm{U}$ & 194.84 & 221.36 & 212.83 & 238.87 & 224.55 & 247.27 \\
\hline \multirow{2}{*}{ Vancouver } & $\mathrm{I}$ & 92.93 & 94.43 & 93.83 & 95.16 & 94.23 & 95.44 \\
& $\mathrm{U}$ & 125.10 & 143.24 & 137.00 & 154.93 & 144.56 & 160.83 \\
\hline \multirow{2}{*}{ Las Vegas } & $\mathrm{I}$ & 26.64 & 26.92 & 26.77 & 27.10 & 26.84 & 27.11 \\
& $\mathrm{U}$ & 35.72 & 40.74 & 38.83 & 45.10 & 40.82 & 46.84 \\
\hline \multirow{2}{*}{ Miami } & $\mathrm{I}$ & 2.25 & 2.26 & 2.25 & 2.29 & 2.26 & 2.31 \\
& $\mathrm{U}$ & 2.90 & 3.41 & 3.14 & 3.90 & 3.32 & 4.33 \\
\hline
\end{tabular}

The results in Tables 7 and 8 show that the energy consumption of the building with an insulated green-roof assembly was not largely dependent on the soil type (i.e., light-weight or heavy-weight). These tables also show that the moisture content of the soil did not have an effect on the variation of cooling and heating loads when the roof was insulated.

For the parametric analysis conducted thereafter, the light-weight soil which consisted of $75 \%$ pumice, $10 \%$ compost and $15 \%$ sand, and with a 50\% saturation level was considered. The thermal properties of the soil at $50 \%$ saturation for the light-weight soil included a density of $840 \mathrm{~kg} / \mathrm{m}^{3}$, a thermal conductivity of $0.28 \mathrm{~W} / \mathrm{m} \cdot \mathrm{K}$, a specific heat of $1500 \mathrm{~J} /(\mathrm{kg} \cdot \mathrm{K})$, an albedo of 0.2 and a thermal diffusivity of $2.85 \times 10^{-7} \mathrm{~m}^{2} \cdot \mathrm{s}^{-1}$.

\subsection{Influence of Leaf Area Index (LAI)}

Leaf Area Index (LAI) is defined as the projected area of all leaves divided by the soil surface area, which typically ranges from 0.001 to 5 [65]. The larger LAI indicates that less of the soil is exposed to solar radiation and as a result the soil surface temperature is lower. In this section an uninsulated green roof with a soil thickness of $7.5 \mathrm{~cm}$, plant albedo of 0.11 and plant height of $30 \mathrm{~cm}$ was considered. Figure 3 shows the temperature variation of a green roof soil, in Vancouver, BC, with different LAI and outdoor air for a typical day in summer and winter. On a typical cold winter day, the soil temperature was warmer than the outdoor air temperature by an average of $6{ }^{\circ} \mathrm{C}, 5.7^{\circ} \mathrm{C}$ and $5.1^{\circ} \mathrm{C}$ when the LAI was $0.1,2$ and 5 , respectively. This was attributed to the thermal storage behavior of the soil, i.e., heat is absorbed into the soil as it transfers from the warm interior to the cold exterior. It should be noted that with LAI equal to 5, the soil surface was still warmer than ambient air which indicates that the insulating behavior of foliage limits the heat losses from the soil surface to the ambient air. On a typical hot summer day, due to the higher rate of solar radiation absorption, the surface temperature was warmer than the outdoor air temperature by an average of $18^{\circ} \mathrm{C}, 12^{\circ} \mathrm{C}$ and $7{ }^{\circ} \mathrm{C}$ for LAI ranging from $0.1,2$ and 5, respectively. It was clear that the soil surface was shaded with higher plant coverage resulting in a lower surface temperature. Similar results and observations were made for the other cities too [61]. 


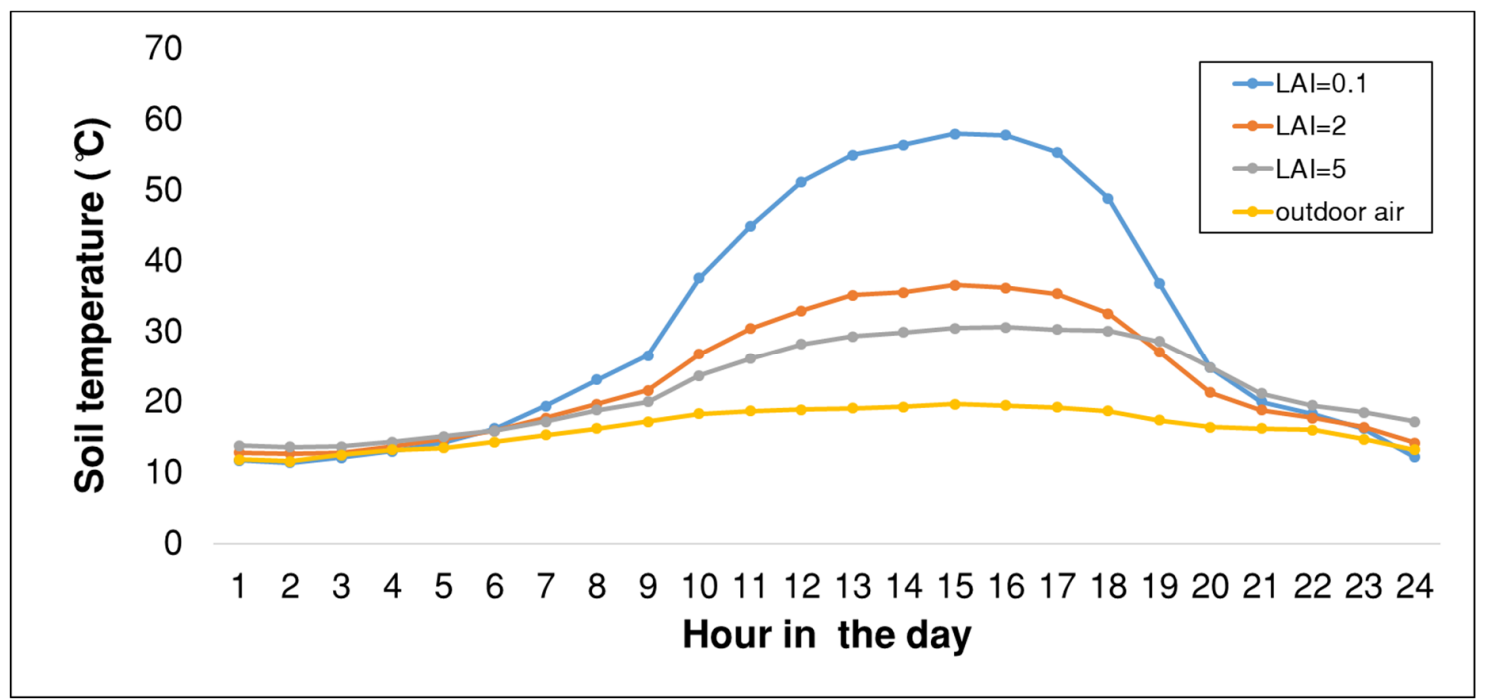

(a)

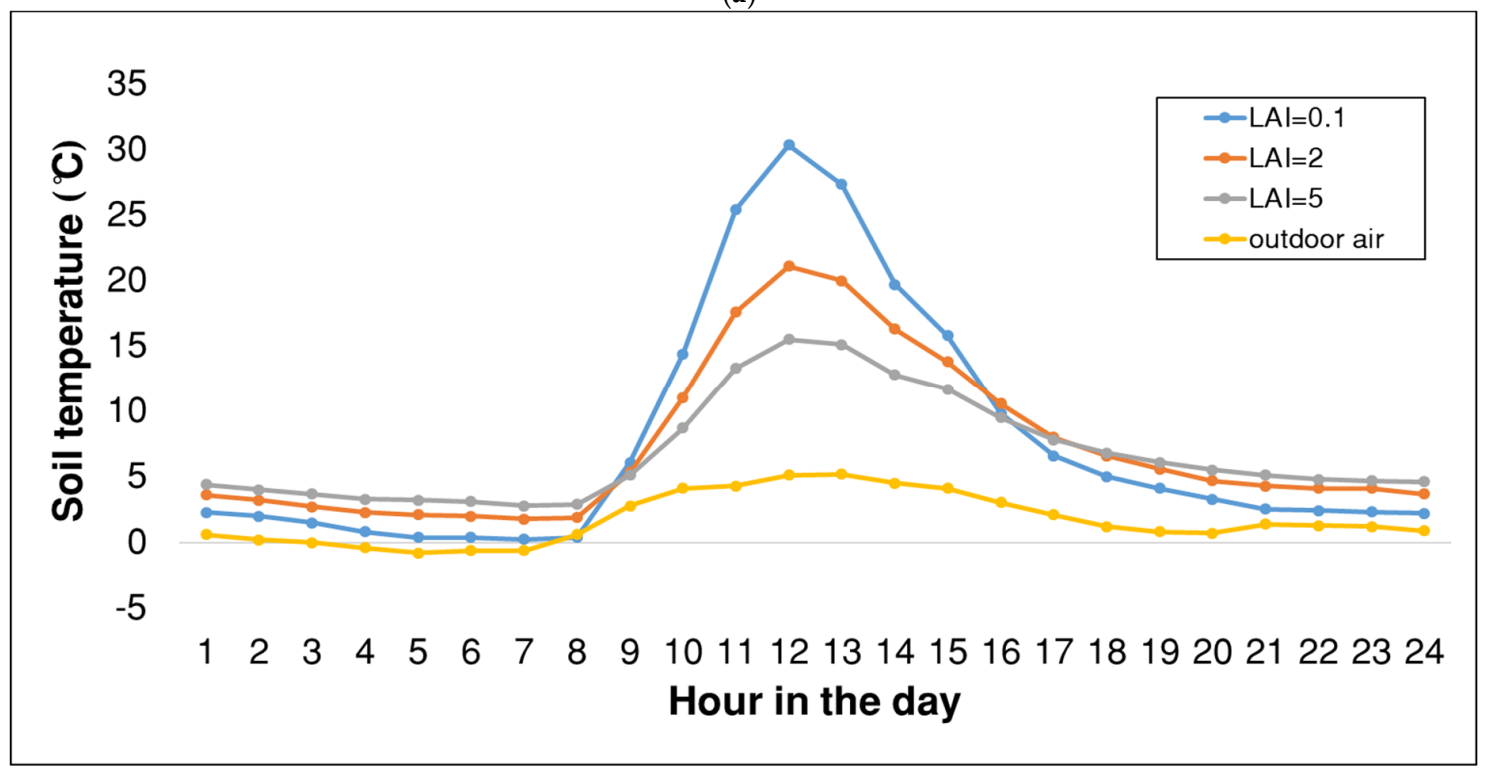

(b)

Figure 3. Hourly variations of soil surface temperature with different leaf area index (LAI) for a typical day in (a) summer and (b) winter for Vancouver.

The LAI has a major effect on the rate of evapotranspiration in green roofs. By increasing the LAI, the rate of evapotranspiration increases as the stomatal resistance of the plants exhibits an inverse relation with LAI. Therefore, it can be concluded that a greater LAI leads to a decrease in cooling load. Equation (1) shows the relationship between the LAI and stomatal resistance [50].

$$
r_{s}=\frac{r_{s, \min }}{L A I} f_{1} f_{2} f_{3}
$$

The actual stomatal resistance varies with the minimum stomatal resistance $\left(r_{s, \text { min }}\right)$ at any time and it has an inverse relationship with LAI. To modify the stomatal resistance equation, fractional multiplying factors $f_{1}, f_{2}$ and $f_{3}$ which functionally relate to the incoming solar radiation and atmospheric moisture, were considered. It should be noted that the rate of evapotranspiration indicates the effectiveness of LAI. However, the plant evapotranspiration individually depends on external conditions such as solar radiation, wind speed, ambient air temperature, relative humidity and soil moisture content. Therefore, 
to compare the effectiveness of LAI on the building energy consumption for the four selected cities, the impacts of the aforementioned variables had to be considered in the analysis.

Because of the difficulty in measurement of the evapotranspiration process, the rate (or flux) of evaporation was defined to indicate the degree of evapotranspiration [66]. Figure 4 compares the average monthly evapotranspiration rate for all four selected cities at two different levels of LAI (5 and 2). It was evident that this rate during the winter was considerably lower than summer because of lower solar radiation and ambient temperature. Additionally, the rate of evapotranspiration was significantly lower when $\mathrm{LAI}=2$, because of less solar radiation absorption by the plants. The heating and cooling load variations with different LAI are shown in Figure 5. It was seen that in Las Vegas higher solar radiation intensity and ambient air temperature as well as lower air relative humidity contributed to the high rate of evapotranspiration and cooling load reduction among all four cities. However, in Miami because of high relative humidity, a low rate of solar radiation and wind velocity [61], the evapotranspiration rate remained almost unchanged even with greater LAI and the cooling load reduced slightly in comparison with other cities. The cooling load reduction in Miami was just $29 \%$ in comparison with $54 \%, 45 \%$ and $41 \%$ reduction in Vancouver, Toronto and Las Vegas respectively as shown in Figure 5. This indicated the effect of solar radiation, wind speed and relative humidity on the effectiveness of LAI and evapotranspiration rate in different climates. The rate of evapotranspiration in Vancouver was higher than that of Toronto during the cooling seasons because Vancouver has lower relative humidity and higher solar insolation than Toronto [61].

As mentioned previously (Figure 3) the soil surface temperature decreased with increasing LAI. The reduction of soil temperature contributed to the higher heat losses through conductive heat transfer in the soil during the heating seasons. The heating load in Las Vegas and Miami increased by almost $21 \%$ and $6.5 \%$, respectively (Figure 5). It should be noted that this trend for Vancouver and Toronto was reversed. This suggested that during the winter the rate of evapotranspiration in these two cities was almost zero compared to that of Las Vegas and Miami because of lower ambient temperatures and solar radiation. In other words, during the winter, Vancouver and Toronto have many cloudy days and the number of sunny days are considerably lower than Miami and Las Vegas [61]. Therefore, greater plant coverage acts as a barrier for heat losses during the winter. The heat loss was reduced by almost $8 \%$ in both cities. It can be seen in Figures $3-5$ that although the LAI had major impacts on the reduction of a long wave and short wave radiation incident on the roofing system during the summer, it influenced the heat losses and heat gains during the winter as well. However, the performance predominantly depends on the climatic conditions. Therefore, LAI plays a key role in decreasing or increasing the heat flux through the green roof. Additionally, in Figure 5 the heating and cooling loads of conventional roofs were compared with green roofs. The insulated conventional roof was insulated with $5 \mathrm{~cm}$ polyurethane. It was seen that the energy usage of building with uninsulated conventional roof was considerably higher than green roofs. It is important to note that the LAI of plants varies throughout the year, and would affect the heating and cooling loads. The results showed that heating and cooling loads variation with change of LAI mainly depended on climate zone. For instance, during the winter where lower LAI ( $\mathrm{LAI}=2$ ) is expected, heating loads for Toronto and Vancouver were higher compared to the LAI $=5$ while for Las Vegas and Miami is lower. Furthermore, it is worthwhile to note that the variety of vegetation affects the depth of snow, duration of snow coverage and substrate temperatures, in particular in cold climates like Toronto. However, in the EnergyPlus 8.8 the effect of freezing of the soil and snow cover in energy modeling were not considered. 


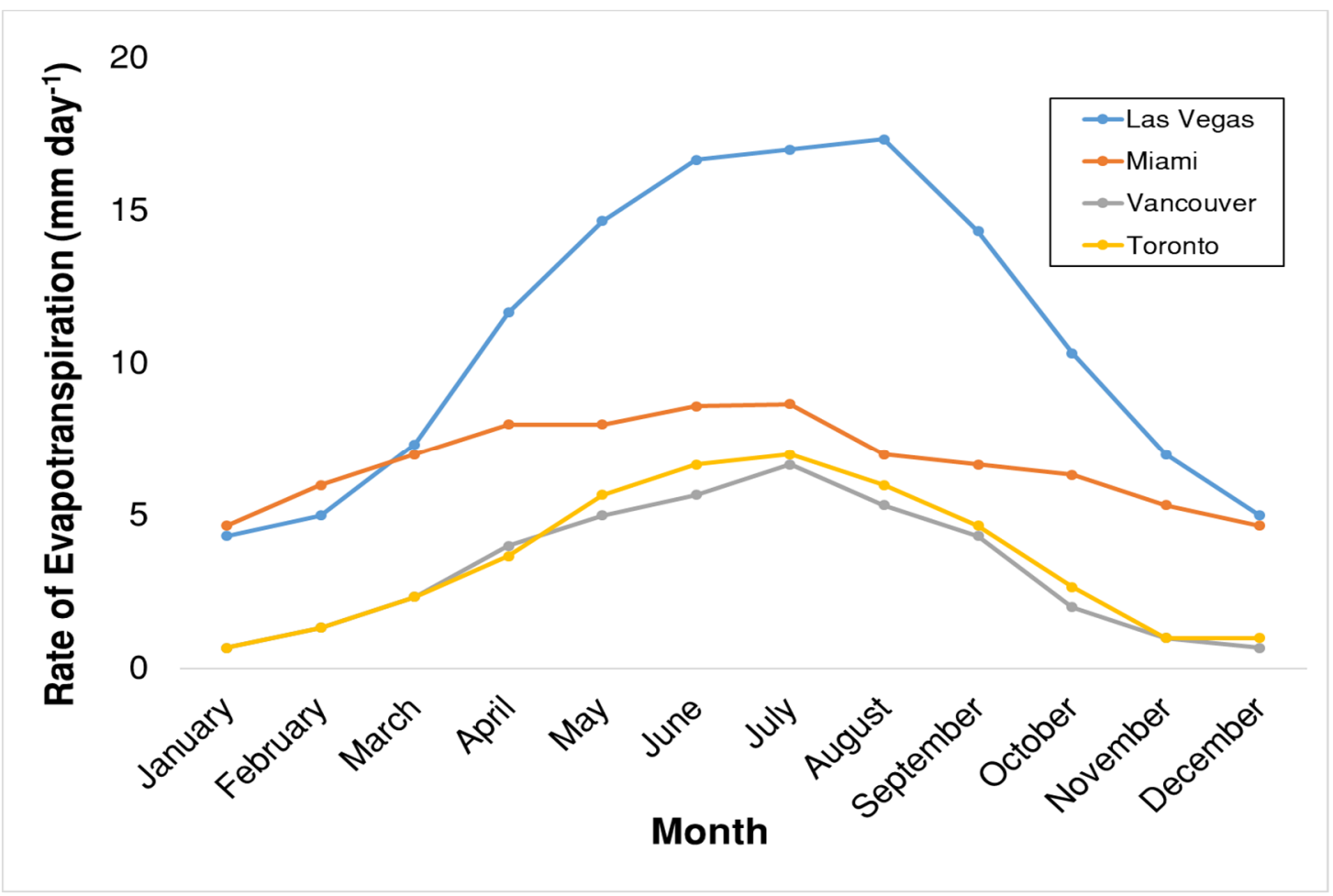

(a)

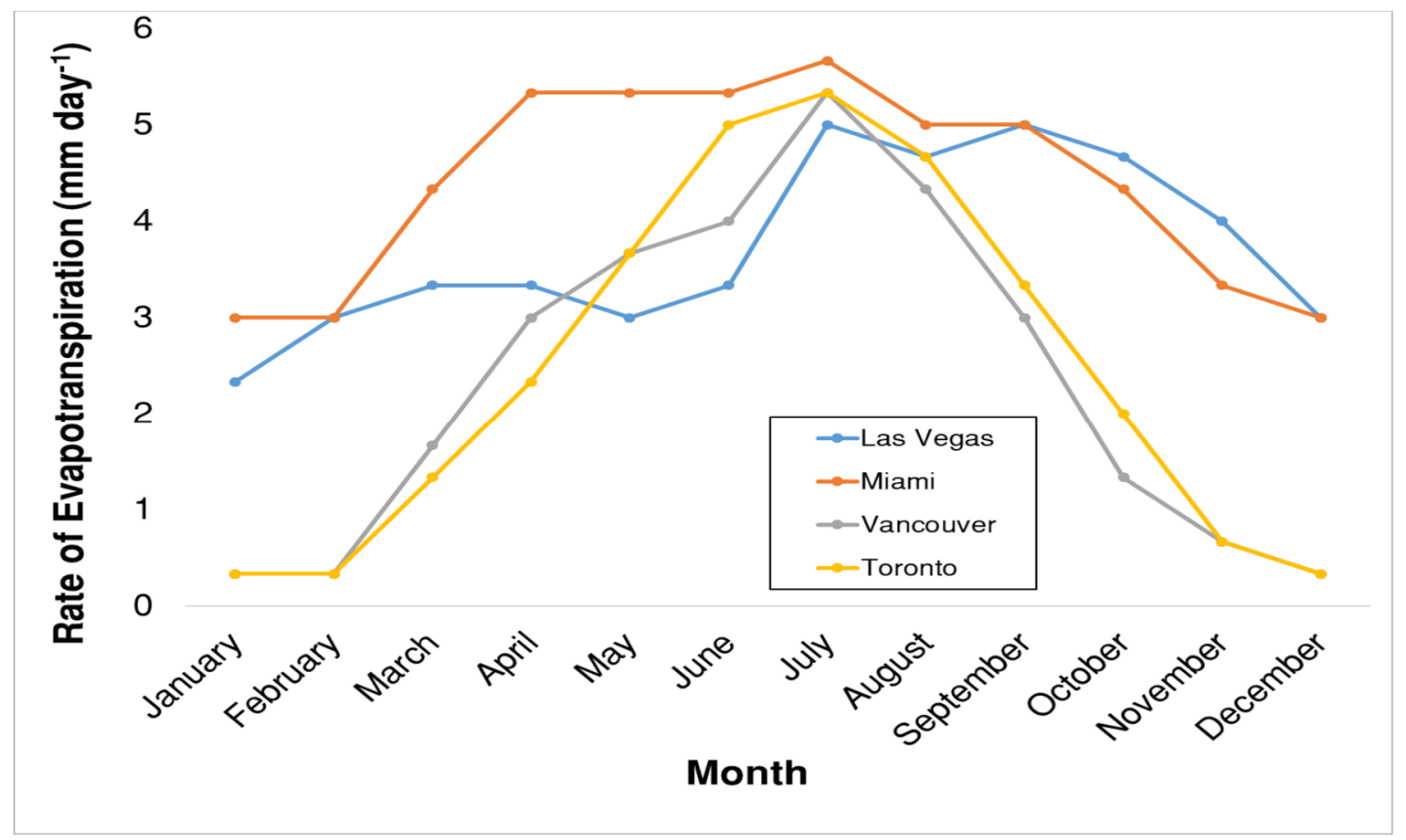

(b)

Figure 4. Monthly average rates of evapotranspiration for the (a) higher plant coverage $(\mathrm{LAI}=5)$ condition and $(\mathbf{b})$ for the lower plant coverage (LAI $=2)$ condition. 


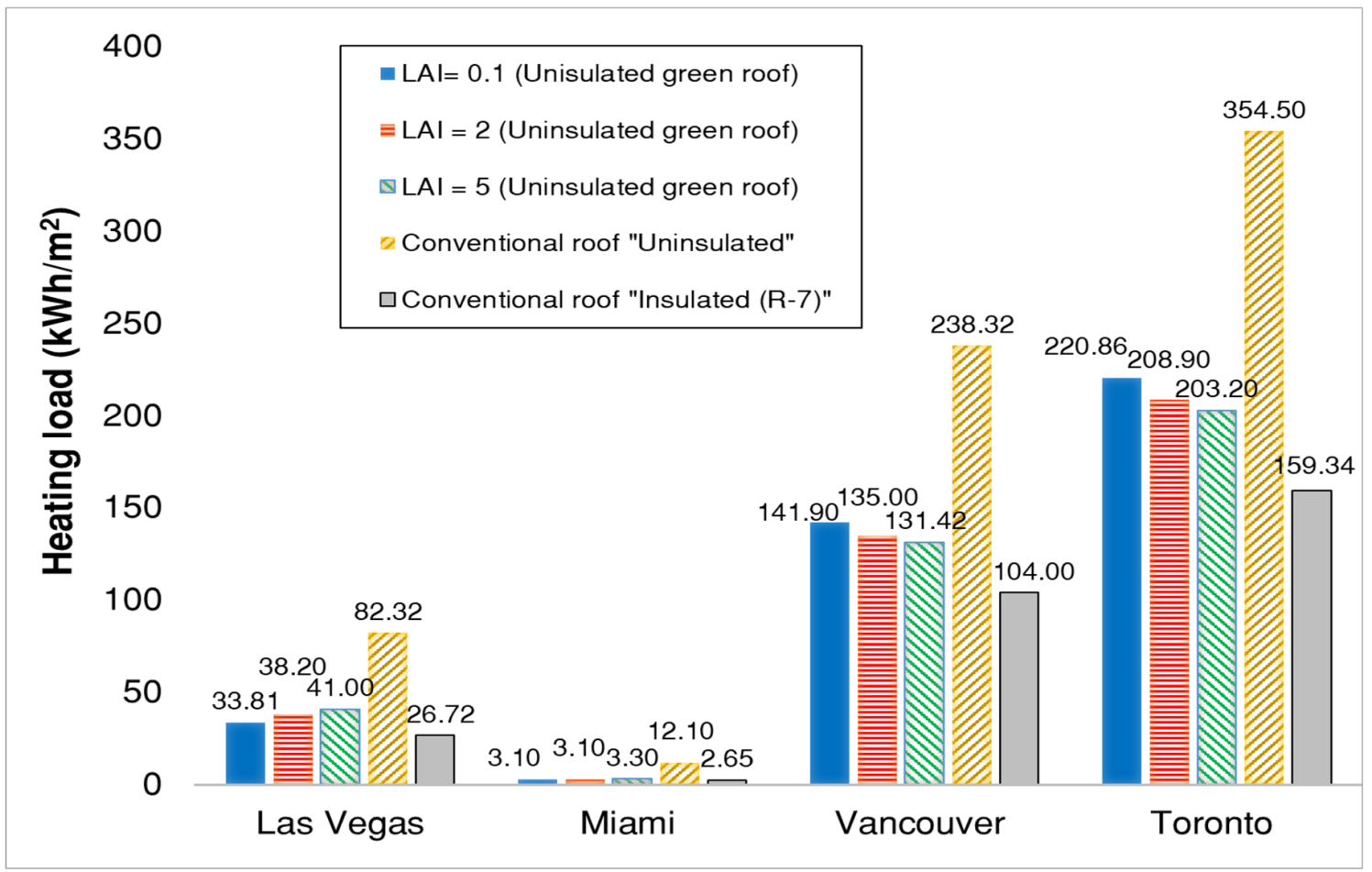

(a)

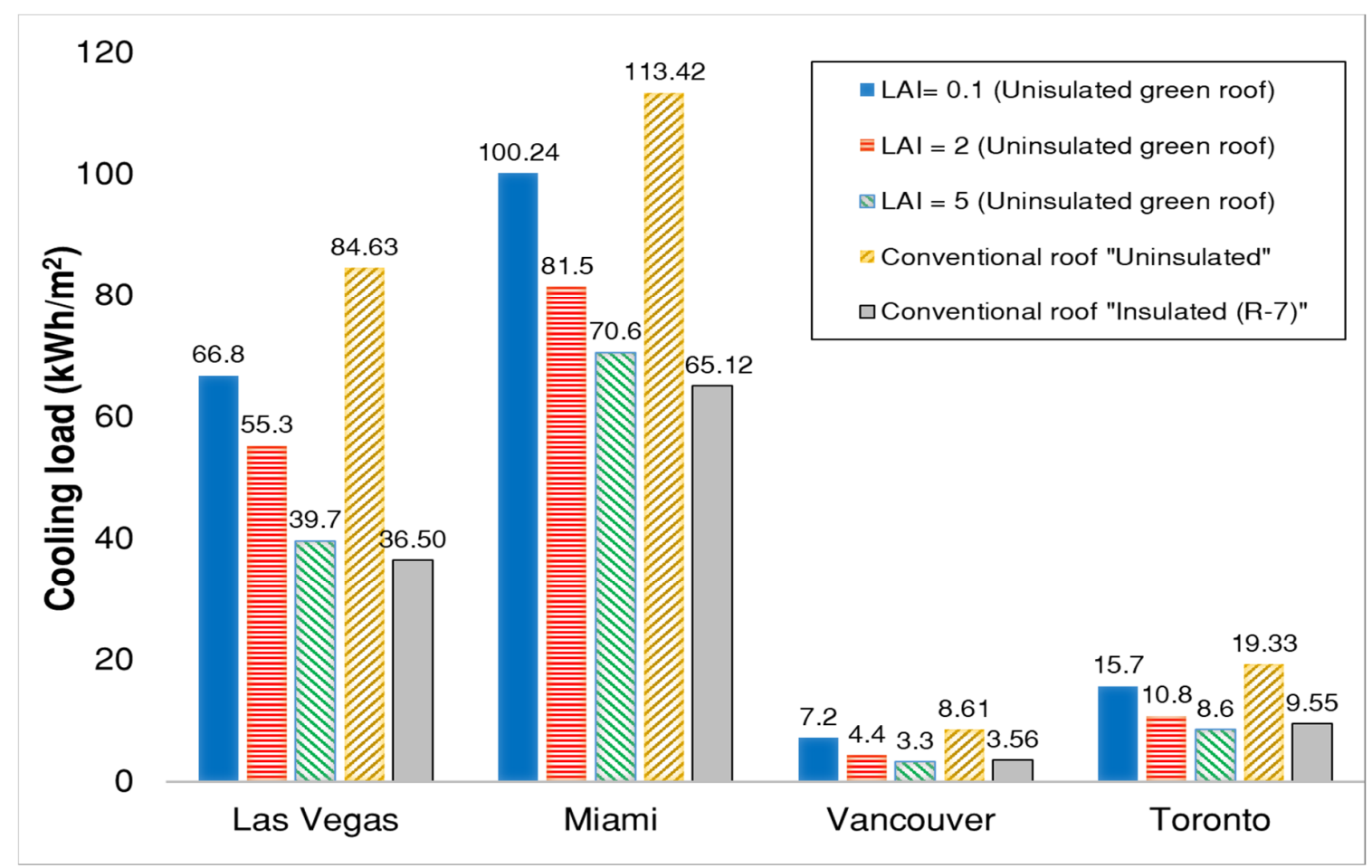

(b)

Figure 5. Sensitivity of the (a) heating load and (b) cooling load with LAI in different climates.

\subsection{Influence of Soil Thickness}

Increasing soil thickness results in lower heat flux because of thermal storage and insulation effects of the soil. The thicker soil contributes to a reduction in the operating costs of the HVAC system, however, it increases the initial costs [65]. In this section an uninsulated green roof with soil thickness of plant albedo of 0.11 and plant height of $30 \mathrm{~cm}$ was considered. It can be seen in Figure 6 that higher 
soil thickness produced higher reduction of heating and cooling load in all locations. The results in Figure $6 \mathrm{~b}$ demonstrated that the highest percentage reduction in cooling load was in Vancouver, which was $27 \%$ when the soil thickness was $15 \mathrm{~cm}$. It can be deduced that, as the summer in Vancouver is cooler compared to the other cities, the thicker soil has greater impacts on the cooling load. The minimum percentage reduction of cooling load was in Miami $(6 \%)$ as it had a hot and humid summer and the extra thermal storage of the soil was not as effective as in other cities because of the low temperature fluctuation during the day. These reductions were lower when the LAI was equal to 5 , which was justifiable because of the cooling effect of the plants. Similarly, as can been seen in Figure 6a during the winter, the soil thickness was more effective when the LAI was low. For instance, with LAI $=2$, the heat loss was reduced by $30 \%$ in Miami when the soil thickness was doubled. However, this reduction in Toronto was found to be lower $(16 \%)$ as a result of the much colder winters. With LAI equal to 5 the radiative heating capability of the thicker soil is reduced as the vegetation cools the roof and increases the heat losses. It is evident from Figure 6 that the soil with a $15 \mathrm{~cm}$ thickness saved energy in all climates. Similar to Figure 5, the heating and cooling loads of conventional roofs were compared with green roofs in Figure 6. It can be seen that the energy usage of a building with an uninsulated conventional roof was considerably higher than green roofs. However, an insulated conventional roof had better performance than a green roof where it was more evident in heating dominated climates. It is important to note that the effect of freezing on the soil on the energy simulation of a green roof in cold climates should be considered. To illustrate, with the frozen soil, the thermal conductivity of soil increased and the insulation effect of growing media would be diminished in this case, which would lead to higher heat losses through the roof.

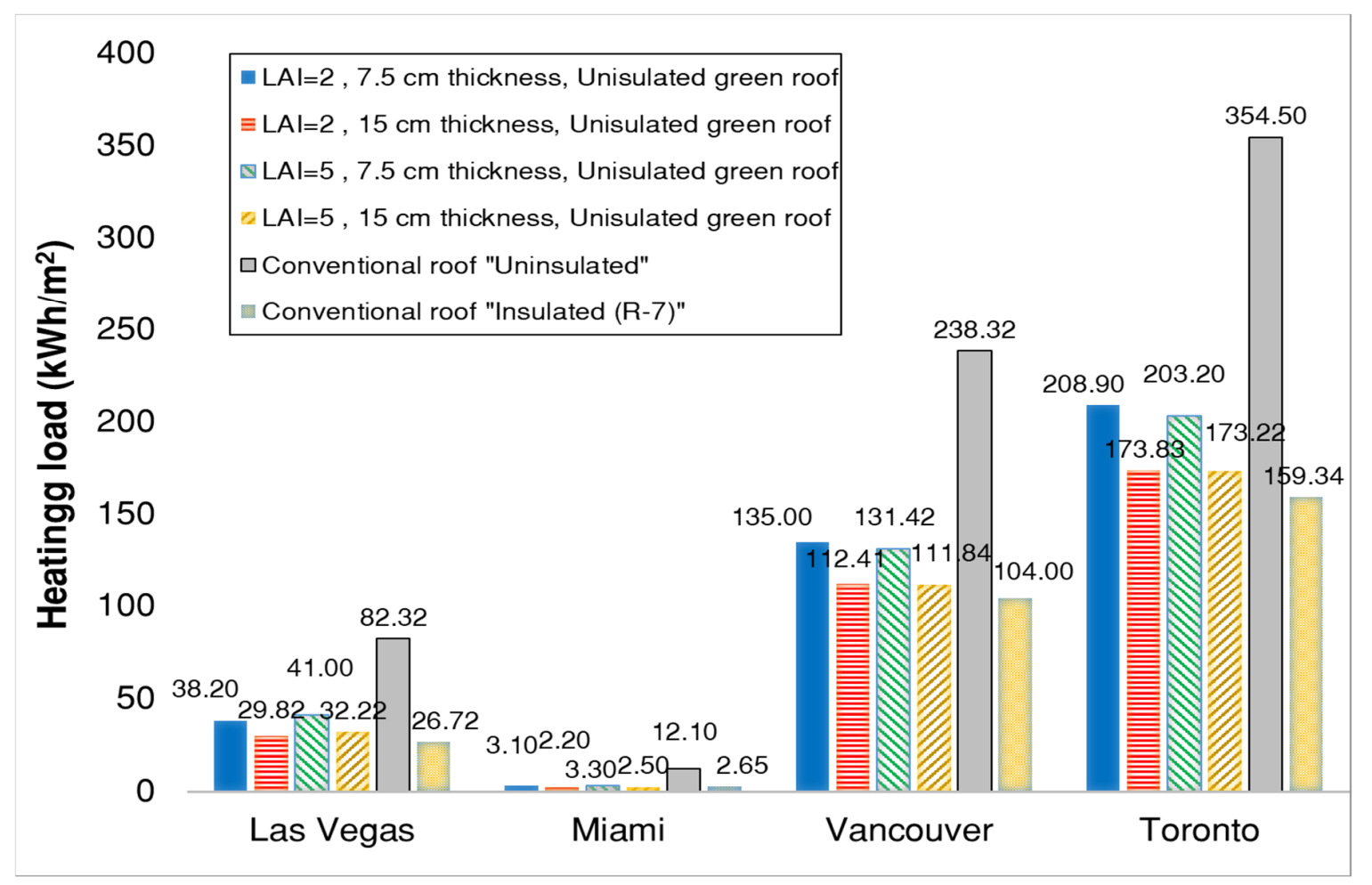

(a)

Figure 6. Cont. 


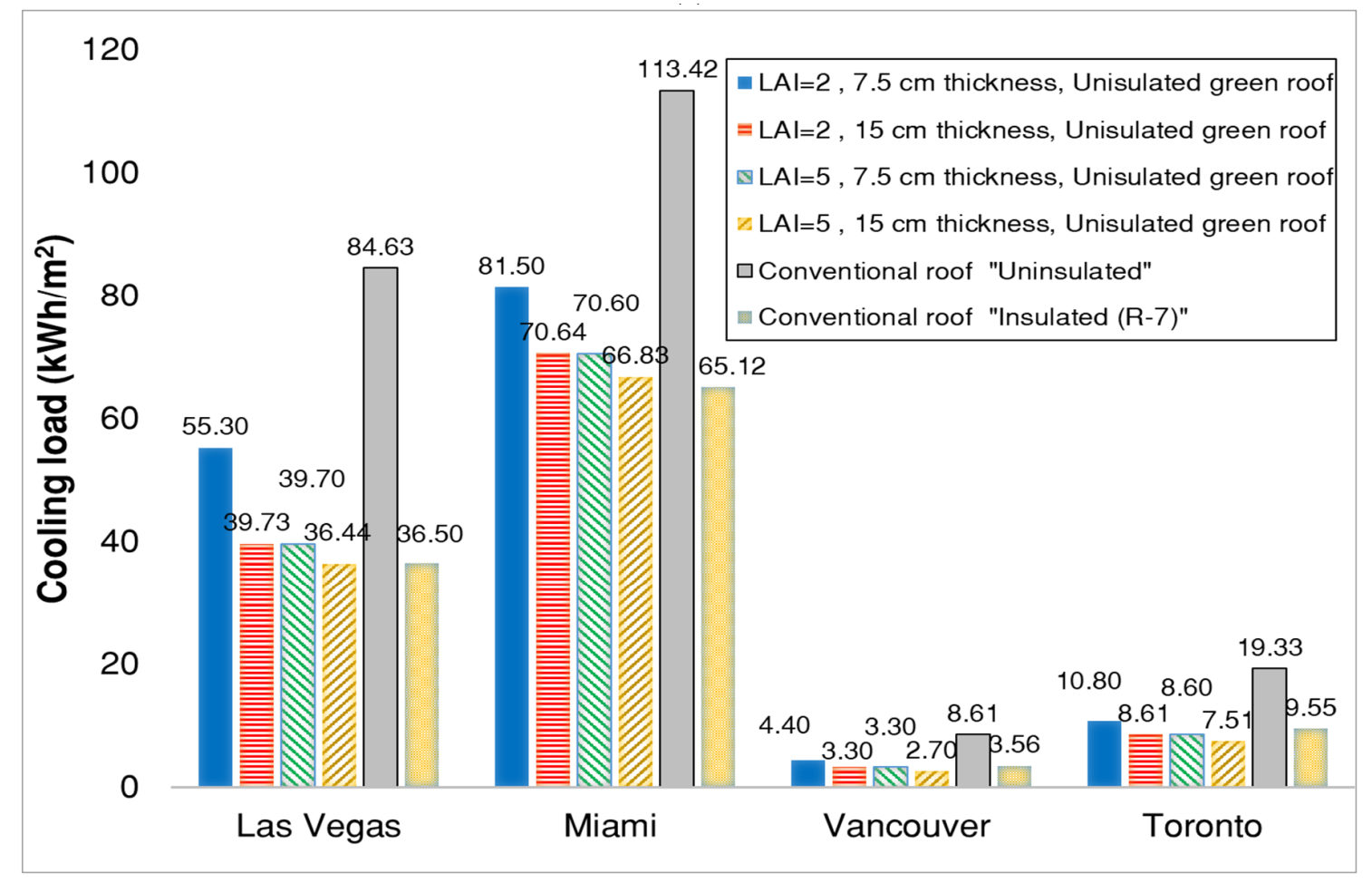

(b)

Figure 6. Sensitivity of (a) heating load and (b) cooling load with LAI and soil thickness in different climates.

\subsection{Influence of Plant Albedo}

The plant surface temperature had major impacts on the energy balance of a green roof [10]. This was due to the convective heat transfer between the leaves surface and air within the canopy. The higher foliage surface temperature results in increases in the ambient air and reduces the mitigating effects. The surface temperature depends on the amount of solar and thermal radiation absorption, emission, convective heat transfers with ambient air and the latent heat flux by transpiration [10]. The variations of vegetation latent heat fluxes, soil temperature and foliage temperature with plant albedo are presented in Figure 7 for a green roof with LAI $=5$ and $15 \mathrm{~cm}$ soil thickness in Vancouver, BC. In this section, an uninsulated green roof with a soil thickness of $15 \mathrm{~cm}$ and LAI of 5 was considered for analysis. The results are available for other cities too [61]. It was observed that the plant with albedo 0.11 had higher foliage and soil temperature due to the higher solar absorption. The higher foliage temperature also contributed to the higher rate of transpiration. Nevertheless, the cooling effect of high transpiration (higher evaporation) was canceled out by the higher surface temperature (higher conduction heat transfer) of the soil. Similar observations are available for other cities too [61].

Similar to the other parameters, the effect of leaf reflectivity on the thermal performance of the green roof was evaluated. The results in Figure 8 show that the plant albedo did not have effect on the energy performance of the green roof because of the tradeoff between the cooling effect of evapotranspiration and the increase in soil temperature. The cooling and heating load in all four cities changed less than $1 \%$ by altering the plant albedo from 0.11 to 0.23 . Therefore, although the plant albedo had a negligible effect on the green roof energy performance, for the cities such as Vancouver and Toronto which are heating dominated climates, the plant with lower reflectivity 0.11 was considered and for the Miami and Las Vegas which are cooling dominated climates the plant with higher reflectivity 0.23 was suitable. It should be noted that the variation of plant color throughout the leaf affected the leaf albedo. However, unlike LAI, from the results it can be concluded that variation plant color during different seasons has a very small effect on the heating and cooling variations. 


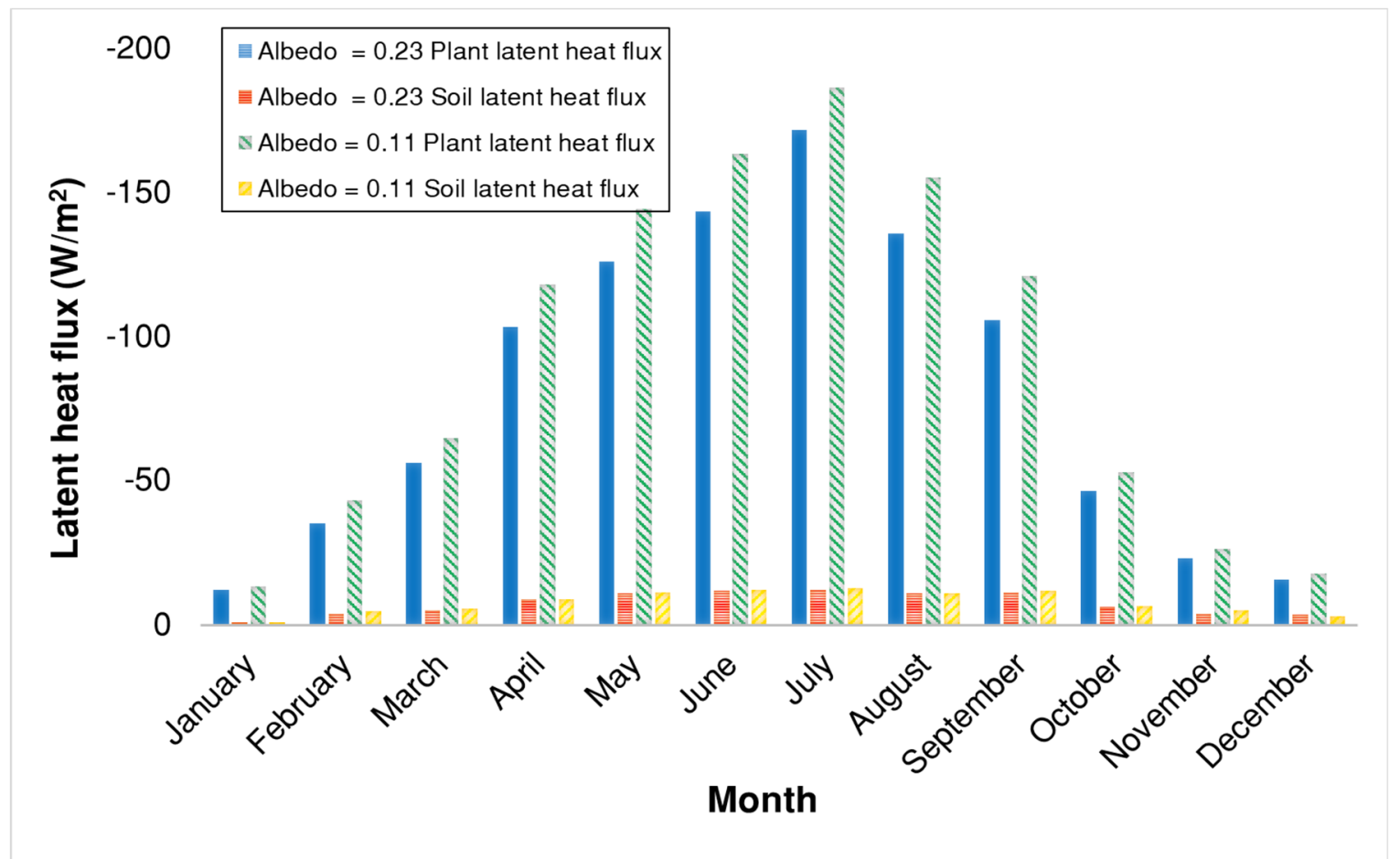

(a)

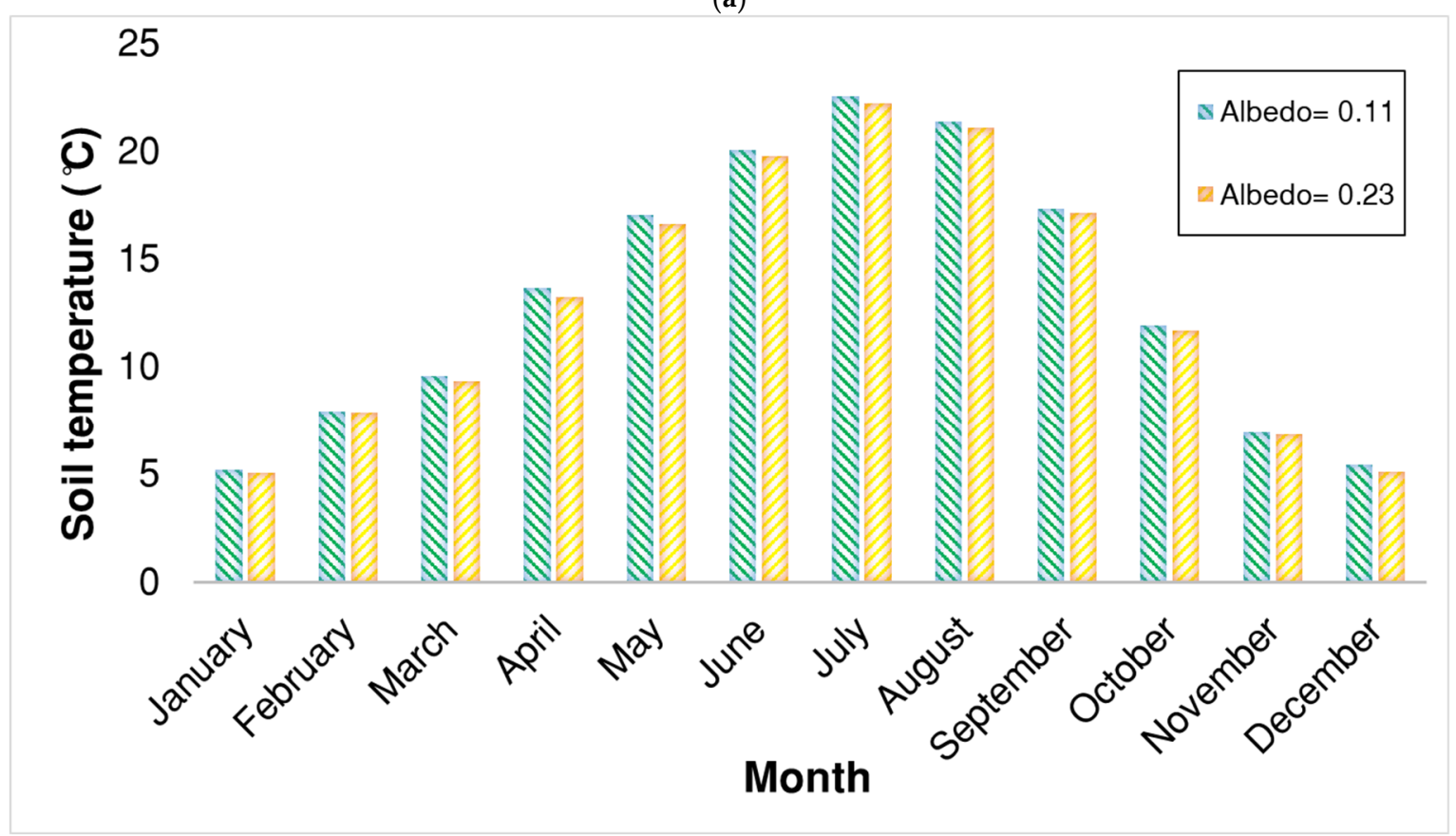

(b)

Figure 7. Cont. 


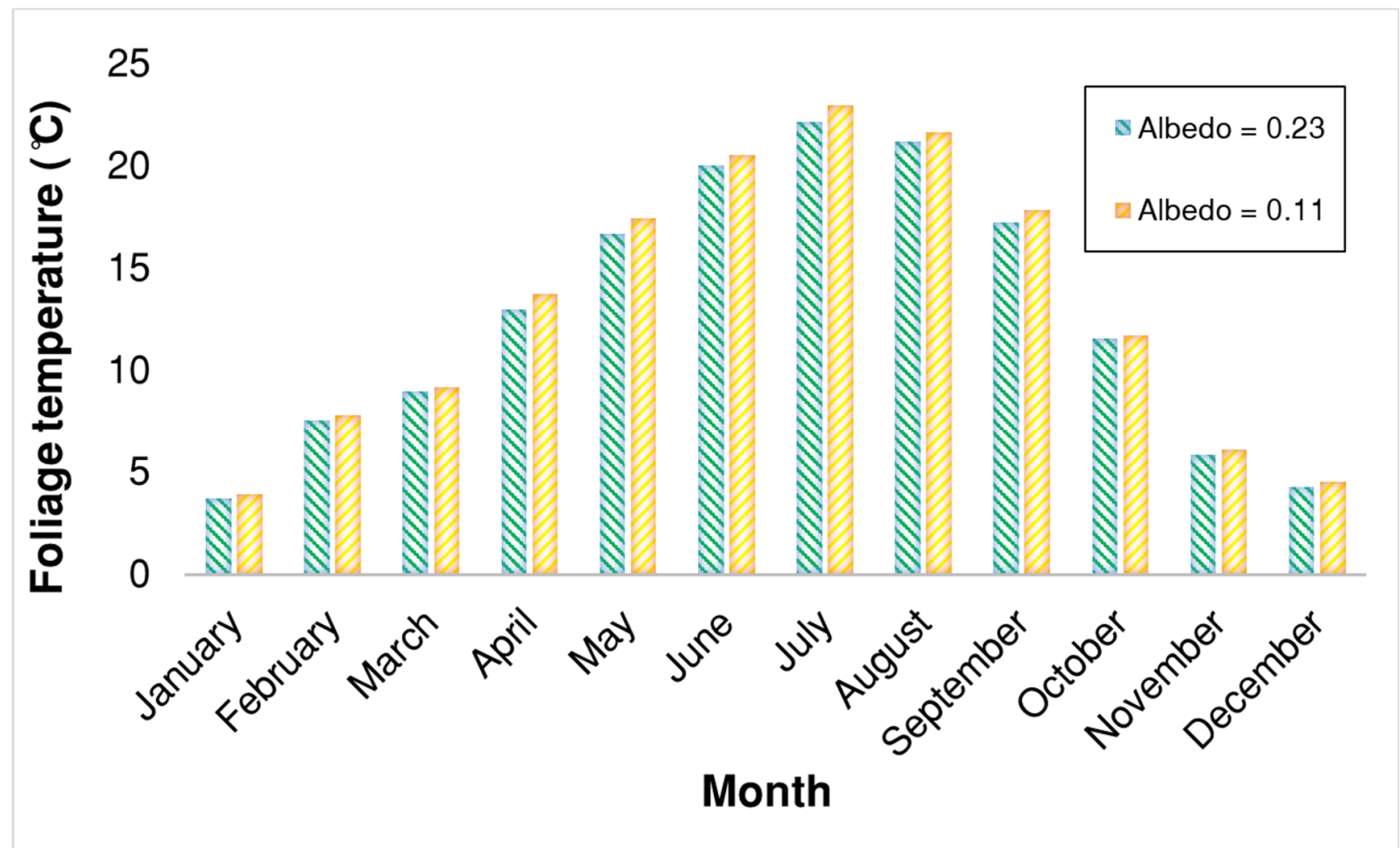

(c)

Figure 7. (a) Effect of plant albedo on the plant and soil latent heat fluxes; (b) monthly average variations in soil temperature; (c) monthly average variations of foliage temperature with plant albedo, in Vancouver, BC.

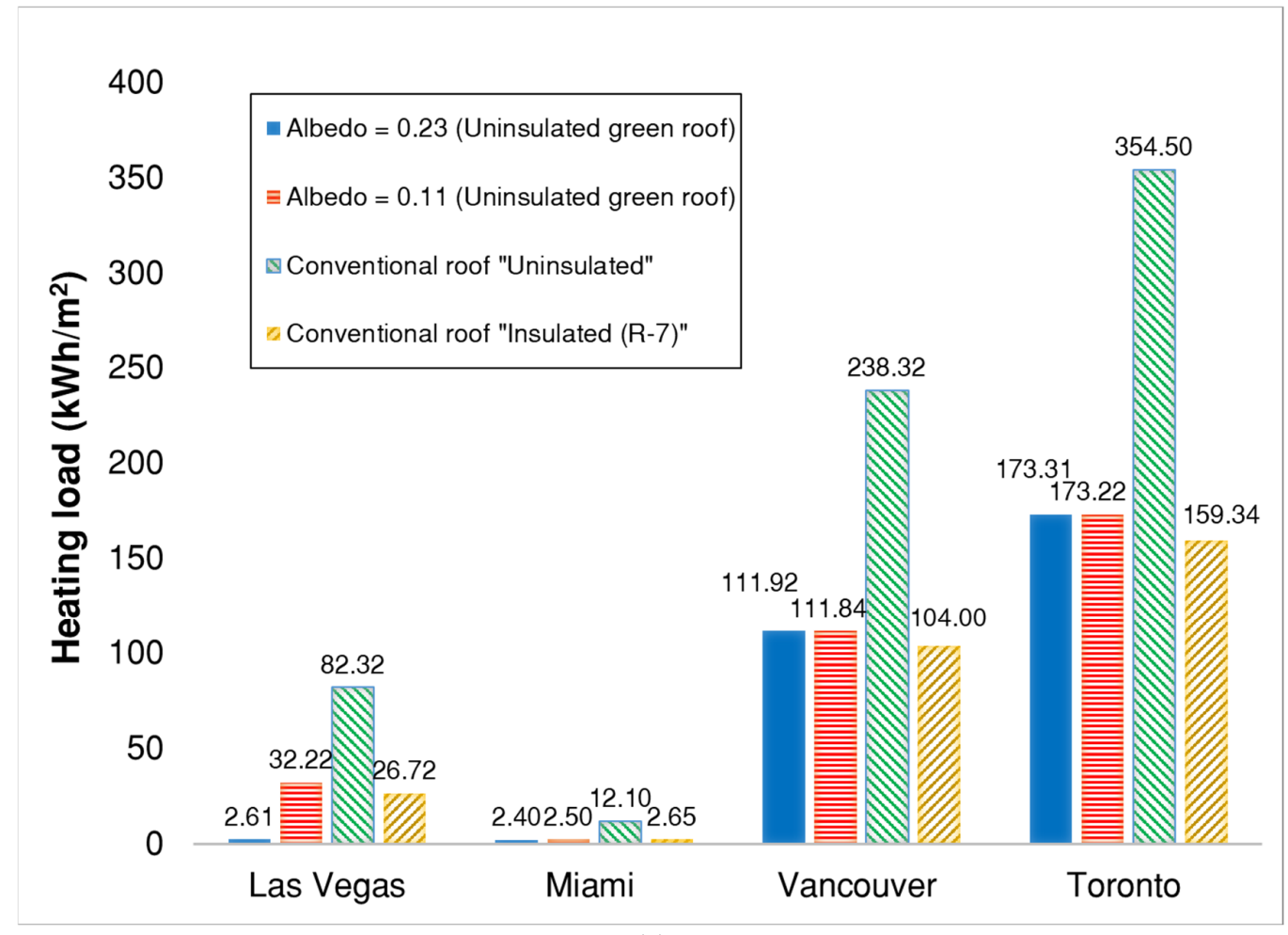

(a)

Figure 8. Cont. 


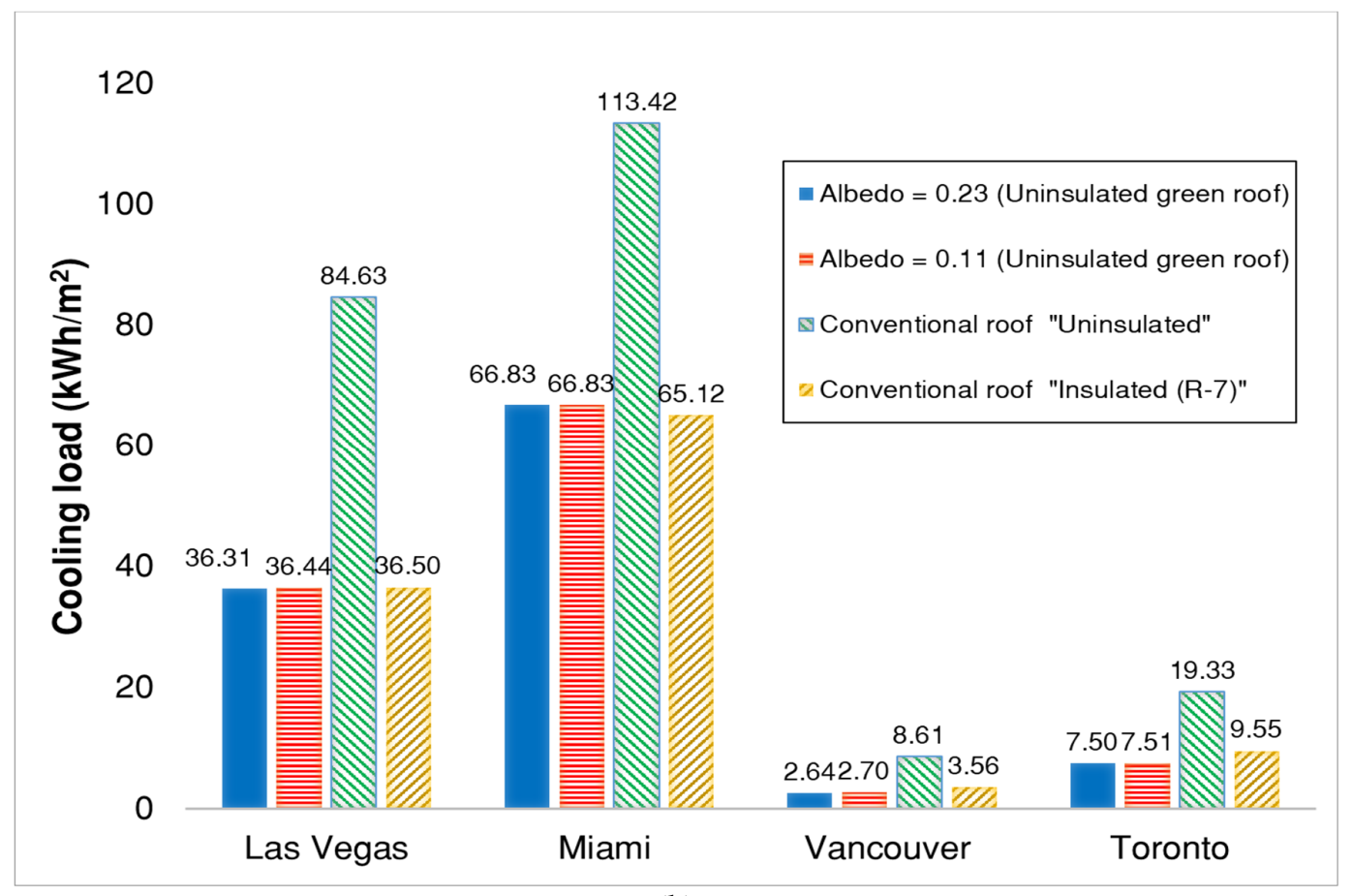

(b)

Figure 8. Sensitivity of (a) heating load, and (b) cooling load, with plant albedo in different climates.

\subsection{Influence of Plant Height}

The plant height, like LAI has impacts on the shading of the soil surface and the rate of evapotranspiration. For instance, with short plants the soil temperature increases more than with tall plants because a larger part of the soil is exposed to the solar radiation. Consequently, the solar radiation absorption by the soil cancels out the cooling impacts of the evapotranspiration process [65]. On the other hand, it is expected that increased plant height will reduce cooling load. With increased plant height, the wind velocity within the canopy increases, leading to higher rates of evapotranspiration. This is strongly related to the formed thick boundary layers on the leaf surface where air close to the leaf surface has marginal movement. Water vapor which leaves the stomata has to transfer through this motionless boundary layer to reach the atmosphere and, hence, the rate of transpiration is slower when the boundary layer is thicker or in other words, when the wind velocity is low.

The aerodynamic resistance factor shows the resistance that is caused by the boundary layer for exchanging moisture. Wind velocity, surface roughness and stability of the atmosphere are the main parameters which influence the aerodynamic resistance. The aerodynamic resistance of a plant is inversely proportional to wind velocity $W_{a}$ [50]. Aerodynamic resistance also affects the leaf surface wetness, such that as the aerodynamic resistance approaches zero, the moisture is transferred rapidly to the leaf surface and evaporated easily [50].

In this section an uninsulated green roof with a soil thickness of $15 \mathrm{~cm}$, plant albedo of 0.11 for cold climates and 0.23 for warm climate, and LAI of 5 was considered. The effect of plant height and the LAI interaction on heating and cooling loads are shown in Figure 9. It can be seen that the growth of the plant does not always lead to a cooling load reduction and the effectiveness of plant height depends on LAI and climate zone. For instance, there was an interactive relationship between LAI and plant height in Miami and Las Vegas. The cooling load in Las Vegas and Miami (unlike Vancouver and Toronto) raised slightly by increasing the plant height when the plant coverage was low $(\mathrm{LAI}=2)$. However, the results expressed that the cooling load decreased by increasing the plant height in all four cities when the LAI was high. Generally, the plant height was not as effective as LAI in the reduction of cooling load. By contrast, the heating load increased as the taller plants resulted in more shading on the soil surface. It is important to notice that the increase in heating load with plant height 
was slightly lower when the LAI was lower. This is justifiable as the surface of the green roof was exposed to more solar radiation when the plant coverage was less. As Las Vegas and Miami are cooling dominated climates, the annual energy savings with a $30 \mathrm{~cm}$ plant is more than with a $10 \mathrm{~cm}$ plant. However, in Toronto and Vancouver (which have heating dominated climates), the $10 \mathrm{~cm}$ plant had better performance on the building energy consumption. The energy performance of a conventional roof with and without insulation was also compared with green roofs. It is clear that by optimizing the green roof system the thermal performance of the green roof was considerably better than an uninsulated conventional roof. Additionally, the green roof had a better performance in the reduction of cooling load compared to the conventional roofs. It should be noted that the plant height and type of plant had an effect on the snow accumulation on green roofs as mentioned in previous sections. This is important as it has a major impact on the energy performance of green roofs and should be considered in the evaluation of green roofs especially for cold climates like Toronto that experience high snowfall during the winter.

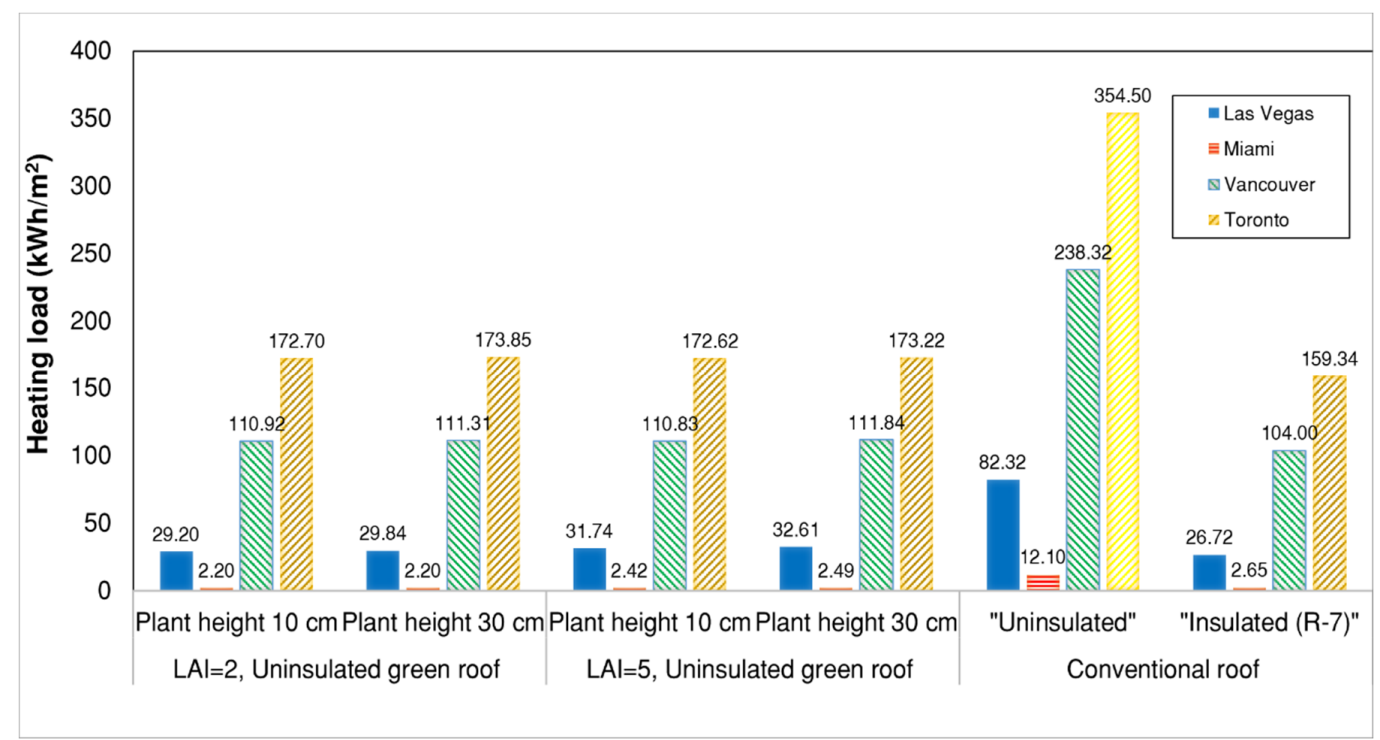

(a)

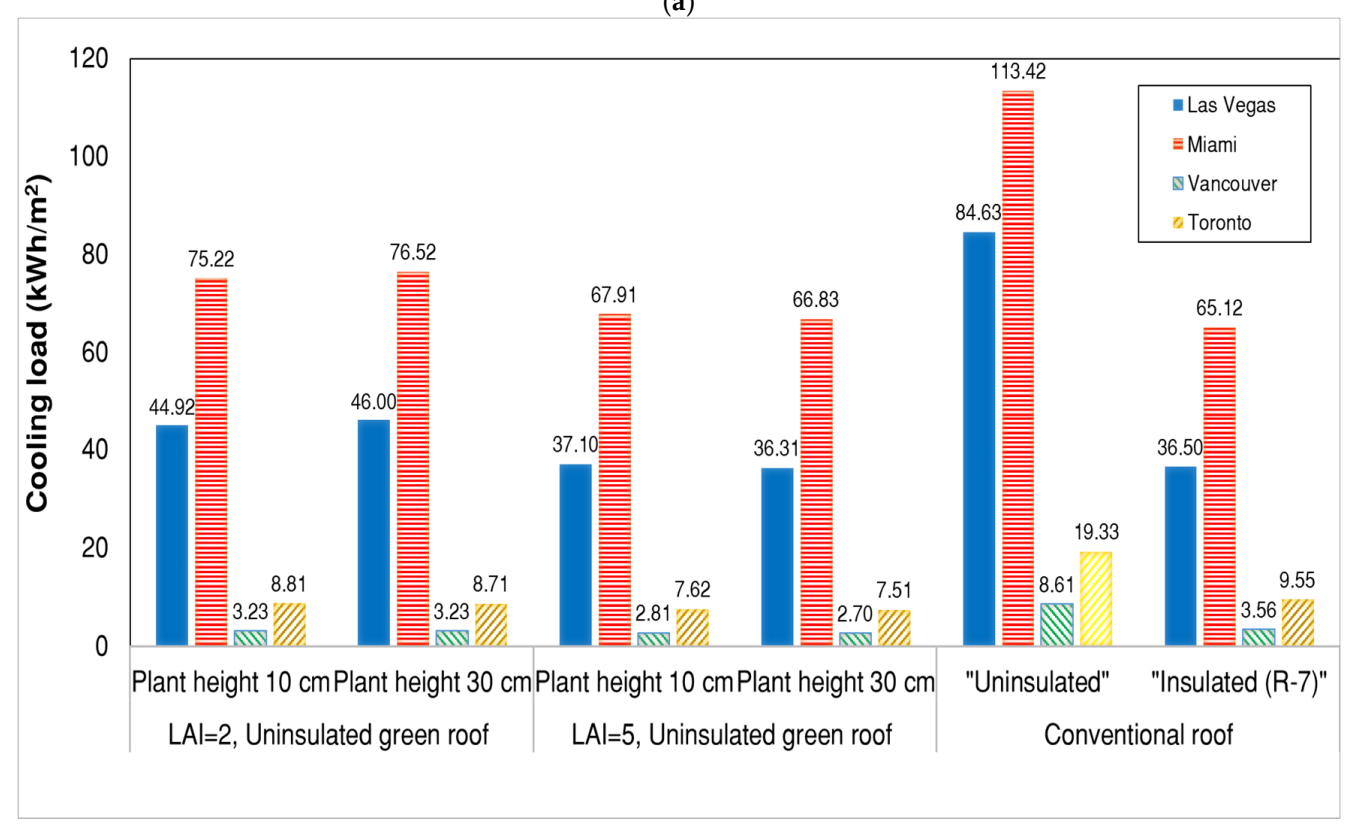

(b)

Figure 9. Sensitivity of (a) heating load and (b) cooling load, with LAI and plant height in different climates. 


\subsection{Influence of Thermal Insulation on an Optimized Green Roof}

In this section an optimized green roof based on parametric studies performed in previous sections was considered. Figure 10 shows the role of thermal insulation on the thermal performance of the school building with optimized design parameters of a green roof as described above. The results demonstrated that thermal insulation would be more effective for the heating dominated climates. The heating load of an optimized vegetated roof in Miami and Las Vegas changed minimally with thermal insulation compared to Vancouver and Toronto. For example, in Miami the uninsulated green roof has almost equal heating load with insulated conventional roof. However, in Las Vegas the heating load for the insulated green roof is slightly better than an uninsulated green roof.

Nevertheless, the uninsulated vegetated roofs in Vancouver and Toronto have considerably higher heating loads than insulated vegetated roofs. It can be concluded that vegetated roofs cannot replace the thermal insulation in heated dominated climates like Canada. However, the insulated green roof with a $5 \mathrm{~cm}$ thermal insulation has almost the same heating load and lower cooling load compared to the conventional roof with a $10 \mathrm{~cm}$ thermal insulation and without a green roof system in these two cities. This means that a green roof could be an appropriate retrofit choice in Canada instead of adding extra insulation to the roof.

On the other hand, green roofs are more effective at reducing cooling loads and the uninsulated green roof has lower cooling loads than the insulated roofs in all cities except Miami. The cooling load decreased with insulation in Miami as the thermal storage was not as effective as it was in other cities because of the low oscillation of ambient air temperature in this warm-humid climate zone. As a result, adding thermal insulation could reduce the cooling load in this climate. In other cities, by increasing the thermal insulation from 0 to $100 \mathrm{~mm}$ the cooling load of the vegetated roof increased. Increasing the thermal insulation levels decouples the indoor environment from the outdoor environment and reduces the ability of the vegetated roof to remove heat from the building. Thus, it can be concluded that there are no benefits from continuously adding insulation to reduce the cooling load.

Table 9 presents the total energy saving of the optimized green roof in comparison with the conventional roof. Here, the conventional roof is considered the reference roof type. It is seen that the annual energy saving varies among the four selected cities. The annual energy consumption with an optimized green roof saved more in heating dominated cities than the cooling dominated cities. The uninsulated optimized green roof performed better than the insulated conventional roof in cooling dominated climates such as Miami and Las Vegas. For instance, installation of optimized green roof assembly on the uninsulated conventional roof saved almost $41 \%$ and $29 \%$ of annual energy consumption in Las Vegas and Miami, respectively.

Table 9. Comparing the energy consumption $\left(\mathrm{kWh} / \mathrm{m}^{2}\right)$ of conventional roof $(\mathrm{CR})$ and green roof (GR) at different level of thermal insulation.

\begin{tabular}{|c|c|c|c|c|c|c|c|c|c|c|}
\hline \multirow{2}{*}{ City } & \multirow{2}{*}{$\begin{array}{c}\text { Energy } \\
\text { Consumption }\end{array}$} & \multicolumn{3}{|c|}{ Without Insulation } & \multicolumn{3}{|c|}{$5 \mathrm{~cm}$ Insulation } & \multicolumn{3}{|c|}{$10 \mathrm{~cm}$ Insulation } \\
\hline & & GR & CR & Diff \% & GR & CR & Diff $\%$ & GR & CR & Diff \% \\
\hline \multirow[t]{3}{*}{ Vancouver } & Heating & 110.83 & 238.32 & 53.49 & 91.11 & 104.00 & 12.39 & 87.14 & 92.52 & 5.81 \\
\hline & Cooling & 2.81 & 8.61 & 67.36 & 2.90 & 3.56 & 18.54 & 2.97 & 3.26 & 8.89 \\
\hline & Total & 227.84 & 382.73 & 40.46 & 207.33 & 221.07 & 6.22 & 203.01 & 209.00 & 2.86 \\
\hline \multirow[t]{3}{*}{ Toronto } & Heating & 172.62 & 354.50 & 51.31 & 139.82 & 159.34 & 12.25 & 132.50 & 141.22 & 6.17 \\
\hline & Cooling & 7.62 & 19.33 & 60.57 & 7.74 & 9.55 & 18.95 & 7.91 & 8.74 & 9.49 \\
\hline & Total & 295.51 & 513.80 & 42.48 & 261.46 & 285.14 & 8.30 & 254.70 & 264.34 & 3.64 \\
\hline \multirow[t]{3}{*}{ Las Vegas } & Heating & 32.61 & 82.32 & 60.38 & 26.72 & 29.44 & 9.23 & 25.54 & 26.66 & 4.20 \\
\hline & Cooling & 36.31 & 84.63 & 57.09 & 36.50 & 43.82 & 16.70 & 36.72 & 40.74 & 9.86 \\
\hline & Total & 183.10 & 309.93 & 40.92 & 177.94 & 190.70 & 6.69 & 177.10 & 183.73 & 3.61 \\
\hline \multirow[t]{3}{*}{ Miami } & Heating & 2.49 & 12.10 & 79.42 & 2.23 & 2.65 & 15.85 & 2.22 & 2.40 & 7.50 \\
\hline & Cooling & 66.83 & 113.42 & 41.07 & 65.12 & 71.94 & 9.48 & 64.82 & 68.30 & 5.09 \\
\hline & Total & 185.34 & 260.11 & 28.74 & 183.50 & 192.22 & 4.54 & 183.14 & 187.44 & 2.29 \\
\hline
\end{tabular}




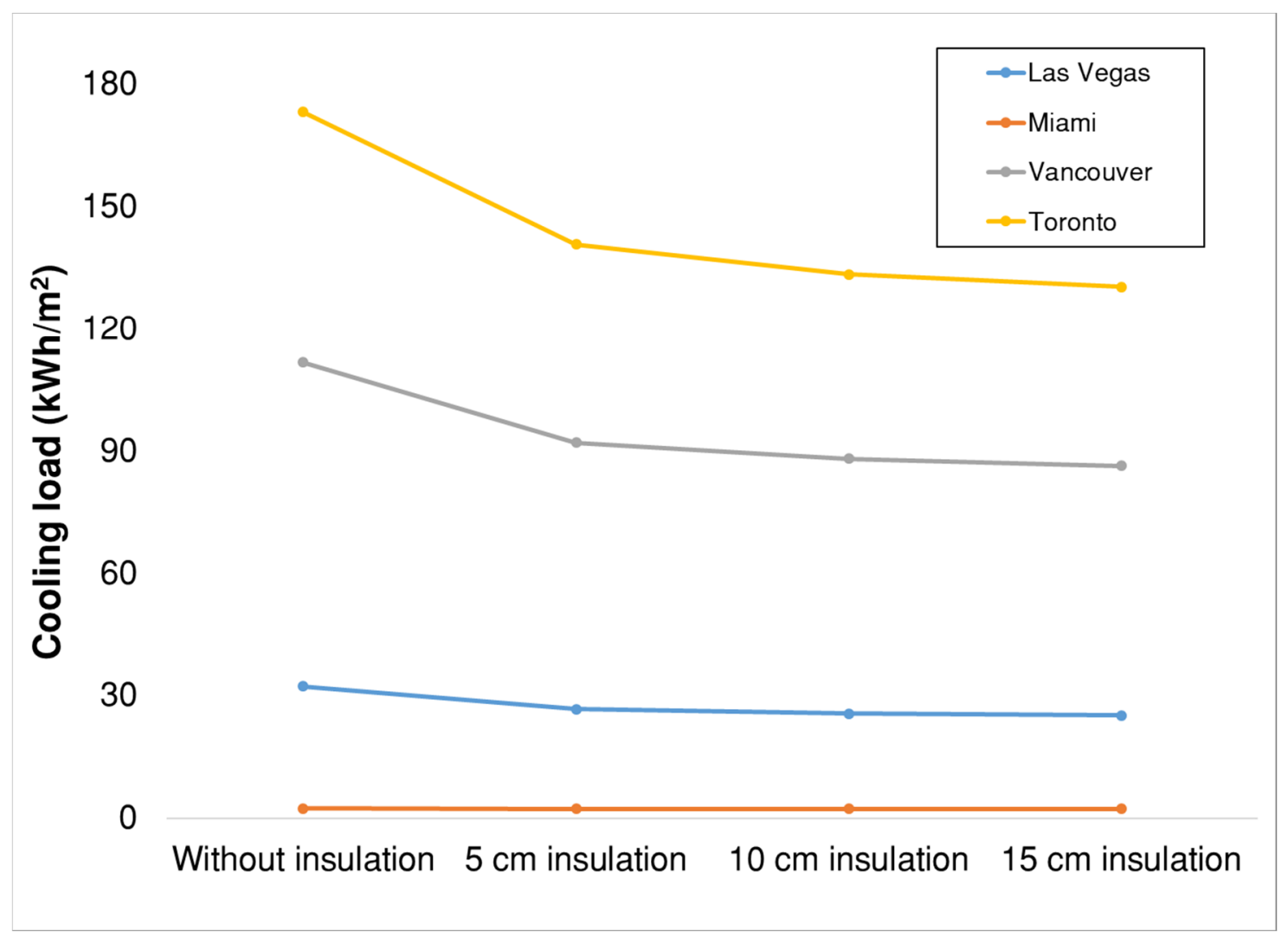

(a)

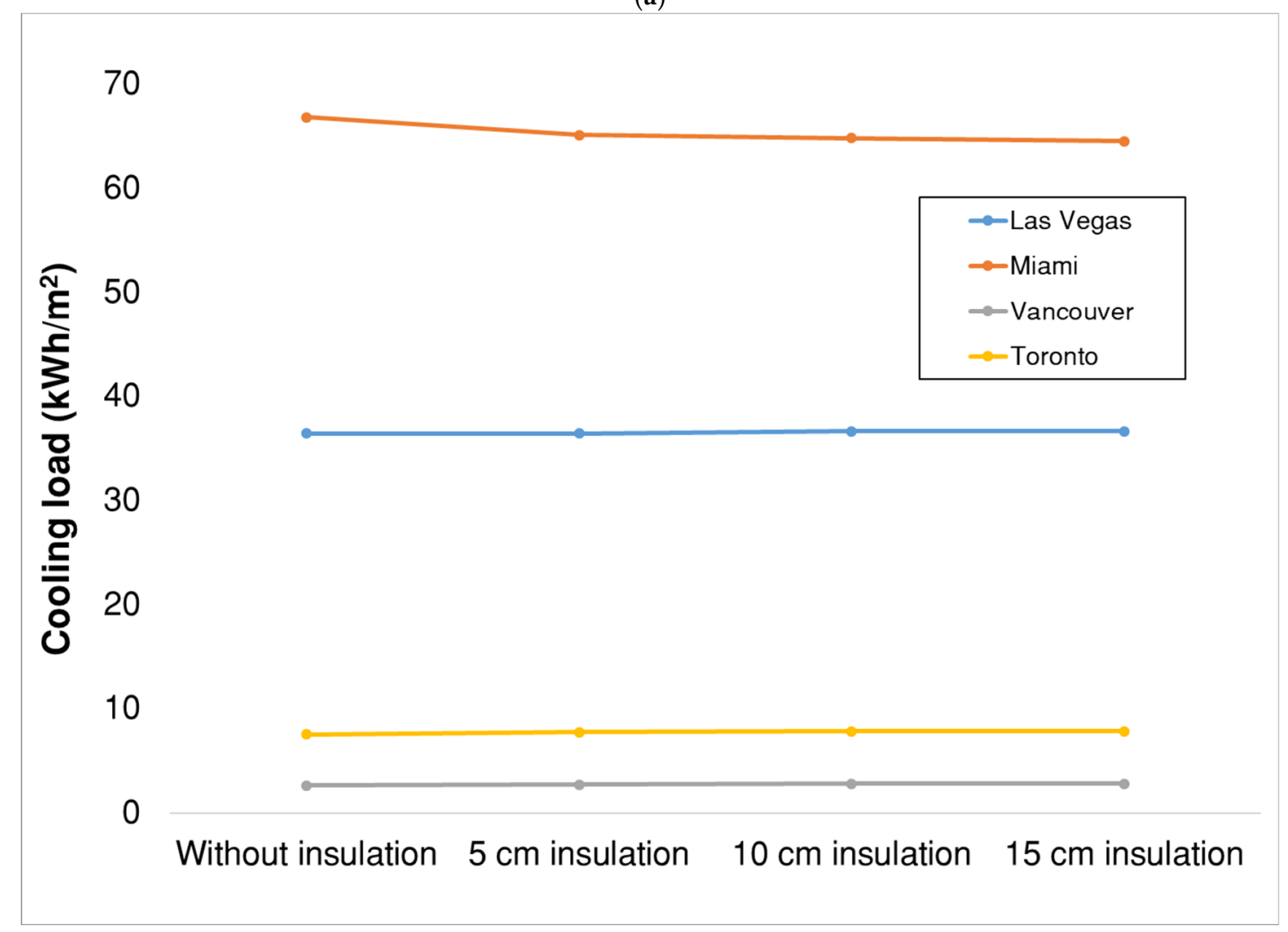

(b)

Figure 10. Sensitivity of (a) heating load and (b) cooling load, with thermal insulation for the optimized green roof in different climates. 
Additionally, the optimized green roof without insulation saved energy almost $4 \%$ more than the poorly insulted conventional roof. Ultimately, the total energy consumption of the school building with the uninsulated green roof was slightly lower than the well-insulated conventional roof in both cities. It can be concluded that in Miami and Las Vegas, the optimized green roof is an appropriate replacement for the insulated conventional roofs.

However, in heating dominated cities, such as Vancouver and Toronto, an uninsulated optimized green roof is not a good choice for replacing the insulated conventional roof. It can be a suitable substitute for retrofitting the building with a poorly insulated roof. For instance, the heating load was reduced by $12.5 \%$ in a retrofitted optimized green roof compared to a conventional roof in both cities. Additionally, the annual energy consumption was saved by $8.30 \%$ and $6.22 \%$ in Toronto and Vancouver, respectively. Hence, in cold climates the thermal performance of the school building could be retrofitted by the green roof instead of adding extra thermal insulation to the conventional roof.

\section{Conclusions}

This study used energy modeling software tool EnergyPlus 8.8 to evaluate the influence of leaf area index (LAI), plant height, leaf albedo, substrate properties, and the roof's thermal insulation on the thermal performance of a secondary school building with extensive green roof in four cities: Las Vegas, NV (USA) and Miami, FL (USA), Toronto, ON (Canada) and Vancouver, BC (Canada). The first two cities are cooling dominated cities while the latter two are heating dominated cities. The following conclusions can be made from this study:

1. The effect of the substrate on the heating load is strongly related to its thermal conductivity. However, the substrate effect on the cooling loads depends on its thermal diffusivity.

2. For the uninsulated green roof, the light-weight substrate had considerably better performance than heavy-weight substrate in all four cities. However, for the insulated green roof there was a small difference between the energy performance of the green roof with a light-weight and heavy-weight substrate.

3. The leaf area index (LAI) is one of the most influential parameters and its effect on the energy performance of a green roof is climate specific. It has major impacts on the cooling reduction in all four selected cities. However, the effect of LAI on the heating load is dependent on the climatic condition. With regard to energy saving, the optimum LAI is 5 for the four selected cities.

4. Thicker soil has better energy savings in all four cities. In summer, the cooling effect of LAI reduces the effectiveness of soil thickness on the cooling load reduction. However, in the heating season, soil thickness has a large effect on the heating load reduction. The thicker soil $(15 \mathrm{~cm})$ has better thermal performance compared to the thinner soil $(7.5 \mathrm{~cm})$.

5. The thermal performance of plant height is affected by the LAI and climate zone of the region. Plant height should be optimal at $30 \mathrm{~cm}$, except in Toronto and Vancouver, where it should be $10 \mathrm{~cm}$.

6. The effect of seasonal variation of LAI on both cooling and heating loads should be considered.

7. Plant albedo has the least effect on the thermal performance of the school. For the heating dominated climate, darker leaves with an albedo of 0.11 and for the cooling dominated climates lighter leaves, with an albedo of 0.23 would be beneficial.

8. Seasonal variation of plant albedo has a small effect on cooling and heating load variation.

9. The green roofs cannot replace thermal insulation to reduce heating loads in cities that experience cold winters. However, it can retrofit the energy performance of the poorly insulated buildings in heating dominated climates.

In addition to the aforementioned conclusions, it has to be noted that that energy saving is one of the benefits of green roofs. Eventually, other environmental benefits of green roofs should also be considered to have a comprehensive evaluation for green roofs' performance in different climate zones. 
Author Contributions: Conceptualization, P.M.; Formal analysis, M.M.; Funding acquisition, P.M.; Investigation, M.M.; Methodology, M.M. and P.M.; Project administration, P.M.; Validation, M.M.; Writing-review and editing, C.V.

Funding: This research received no external funding.

Acknowledgments: The authors would like thank the four reviewers for their insightful reviews that greatly improved this paper.

Conflicts of Interest: The authors declare no conflict of interest.

\section{References}

1. Vera, S.; Pinto, C.; Tabares-Velasco, P.C.; Bustamante, W.; Victorero, F.; Gironás, J.; Bonilla, C.A. Influence of vegetation, substrate, and thermal insulation of an extensive vegetated roof on the thermal performance of retail stores in semiarid and marine climates. Energy Build. 2017, 146, 312-321. [CrossRef]

2. Valipour, M. Future of agricultural water management in Africa. Arch. Agron. Soil Sci. 2015, 61, 907-927. [CrossRef]

3. Valipour, M. Land use policy and agricultural water management of the previous half of century in Africa. Appl. Water Sci. 2015, 5, 367-395. [CrossRef]

4. Jaffal, I.; Ouldboukhitine, S.-E.; Belarbi, R. A comprehensive study of the impact of green roofs on building energy performance. Renew. Energy 2012, 43, 157-164. [CrossRef]

5. Getter, K.L.; Rowe, D.B.; Andresen, J.A. Quantifying the effect of slope on extensive green roof stormwater retention. Ecol. Eng. 2007, 31, 225-231. [CrossRef]

6. Vijayaraghavan, K. Green roofs: A critical review on the role of components, benefits, limitations and trends. Renew. Sustain. Energy Rev. 2016, 57, 740-752. [CrossRef]

7. Teemusk, A.; Mander, Ü. Rainwater runoff quantity and quality performance from a greenroof: The effects of short-term events. Ecol. Eng. 2007, 30, 271-277. [CrossRef]

8. Berndtsson, J.C. Green roof performance towards management of runoff water quantity and quality: A review. Ecol. Eng. 2010, 36, 351-360. [CrossRef]

9. Alexandri, E.; Jones, P. Temperature decreases in an urban canyon due to green walls and green roofs in diverse climates. Build. Environ. 2008, 43, 480-493. [CrossRef]

10. Karachaliou, P.; Santamouris, M.; Pangalou, H. Experimental and numerical analysis of the energy performance of a large scale intensive green roof system installed on an office building in Athens. Energy Build. 2016, 114, 256-264. [CrossRef]

11. Takebayashi, H.; Moriyama, M. Surface heat budget on green roof and high reflection roof for mitigation of urban heat island. Build. Environ. 2007, 42, 2971-2979. [CrossRef]

12. van Renterghem, T.; Botteldooren, D. In-situ measurements of sound propagating over extensive green roofs. Build. Environ. 2011, 46, 729-738. [CrossRef]

13. Teemusk, A.; Mander, Ü. Greenroof potential to reduce temperature fluctuations of a roof membrane: A case study from Estonia. Build. Environ. 2009, 44, 643-650. [CrossRef]

14. Brenneisen, S. Space for urban wildlife: Designing green roofs as habitats in Switzerland. Urban. Habitats 2006, 4, 27-36.

15. Brenneisen, S. The Benefits of Biodiversity from Green Roofs-Key Design Consequences; University of Applied Sciences: Wadenswil, Switzerland, 2003; pp. 1-9.

16. Williams, N.S.; Lundholm, J.; MacIvor, J.S. Do green roofs help urban biodiversity conservation? J. Appl. Ecol. 2014, 51, 1643-1649. [CrossRef]

17. Ascione, F.; Bianco, N.; de'Rossi, F.; Turni, G.; Vanoli, G.P. Green roofs in European climates. Are effective solutions for the energy savings in air-conditioning? Appl. Energy 2013, 104, 845-859. [CrossRef]

18. Abuseif, M.; Gou, Z. A review of roofing methods: Construction features, heat reduction, payback period and climatic responsiveness. Energies 2018, 11, 3196. [CrossRef]

19. Getter, L.K.; Rowe, D.B.; Cregg, B.M. Solar radiation intensity influences extensive green roof plant communities. Urban. For. Urban. Green. 2009, 8, 269-281. [CrossRef]

20. Heusinger, J.; Stephan, W. Extensive green roof $\mathrm{CO}^{2}$ exchange and its seasonal variation quantified by eddy covariance measurements. Sci. Total Environ. 2017, 607, 623-632. [CrossRef] 
21. Akther, M.; He, J.; Chu, A.; Huang, J.; Van Duin, B. A review of green roof applications for managing urban stormwater in different climatic zones. Sustainability 2018, 10, 2864. [CrossRef]

22. Foustalieraki, M.; Assimakopoulos, M.; Santamouris, M.; Pangalou, H. Energy performance of a medium scale green roof system installed on a commercial building using numerical and experimental data recorded during the cold period of the year. Energy Build. 2017, 135, 33-38. [CrossRef]

23. DeNardo, J.C.; Jarrett, A.; Manbeck, H.; Beattie, D.; Berghage, R. Green roof mitigation of stormwater and energy usage. In Proceedings of the ASAE Annual Meeting, American Society of Agricultural and Biological Engineers, Las Vegas, NV, USA, 27-30 July 2003; p. 1.

24. Bevilacqua, P.; Mazzeo, D.; Bruno, R.; Arcuri, N. Experimental investigation of the thermal performances of an extensive green roof in the Mediterranean area. Energy Build. 2016, 122, 63-79. [CrossRef]

25. Babak, R.; Tenpierik, M.J.; van den Dobbelsteen, A. The impact of greening systems on building energy performance: A literature review. Renew. Sustain. Energy Rev. 2015, 45, 610-623.

26. Wong, N.H.; Cheong, D.K.W.; Yan, H.; Soh, J.; Ong, C.; Sia, A. The effects of rooftop garden on energy consumption of a commercial building in Singapore. Energy Build. 2003, 35, 353-364. [CrossRef]

27. Theodosiou, T.G. Summer period analysis of the performance of a planted roof as a passive cooling technique. Energy Build. 2003, 35, 909-917. [CrossRef]

28. Vera, S.; Pinto, C.; Victorero, F.; Bustamante, W.; Bonilla, C.; Gironás, J.; Rojas, V. Influence of plant and substrate characteristics of vegetated roofs on a supermarket energy performance located in a semiarid climate. Energy Procedia 2015, 78, 1171-1176. [CrossRef]

29. Sailor, D.J.; Elley, T.B.; Gibson, M. Exploring the building energy impacts of green roof design decisions-A modeling study of buildings in four distinct climates. J. Build. Phys. 2012, 35, 372-391. [CrossRef]

30. Getter, K.L.; Rowe, D.B.; Andresen, J.A.; Wichman, I.S. Seasonal heat flux properties of an extensive green roof in a Midwestern US climate. Energy Build. 2011, 43, 3548-3557. [CrossRef]

31. Silva, C.M.; Gomes, M.G.; Silva, M. Green roofs energy performance in Mediterranean climate. Energy Build. 2016, 116, 318-325. [CrossRef]

32. Mukherjee, S.; la Roche, P.; Konis, K.; Choi, J.H. Thermal performance of green roofs: A parametric study through energy modeling in different climates. In Proceedings of the Passive Low Energy Architecture Conference PLEA, Munich, Germany, 10-12 September 2013.

33. Gomes, M.G.; Silva, C.M.; Valadas, A.S.; Silva, M. Impact of Vegetation, Substrate, and Irrigation on the Energy Performance of Green Roofs in a Mediterranean Climate. Water 2019, 11, 2016. [CrossRef]

34. Lundholm, J.T.; Weddle, B.M.; MacIvor, J.S. Snow depth and vegetation type affect green roof thermal performance in winter. Energy Build. 2014, 84, 299-307. [CrossRef]

35. Tang, X.; Qu, M. Phase change and thermal performance analysis for green roofs in cold climates. Energy Build. 2016, 121, 165-175. [CrossRef]

36. Akbari, H.; Konopacki, S. Energy effects of heat-island reduction strategies in Toronto, Canada. Energy 2004, 29, 191-210. [CrossRef]

37. Liu, K.; Baskaran, B. Thermal performance of green roofs through field evaluation. In Proceedings of the First North American Green Roof Infrastructure Conference, Awards and Trade Show, Chicago, IL, USA, 29-30 May 2003; pp. 29-30.

38. Zhao, M.; Srebric, J. Assessment of green roof performance for sustainable buildings under winter weather conditions. J. Cent. South. Univ. 2012, 19, 639-644. [CrossRef]

39. Connelly, M.; Liu, K. Green roof research in British Columbia: An overview. In Proceedings of the 3rd North American Green Roof Conference: Greening rooftops for sustainable communities, Washington, DC, USA, 4-6 May 2005; pp. 4-6.

40. Berardi, U. The outdoor microclimate benefits and energy saving resulting from green roofs retrofits. Energy Build. 2016, 121, 217-229. [CrossRef]

41. Niachou, A.; Papakonstantinou, K.; Santamouris, M.; Tsangrassoulis, A.; Mihalakakou, G. Analysis of the green roof thermal properties and investigation of its energy performance. Energy Build. 2001, 33, 719-729. [CrossRef]

42. Zhao, M.; Tabares-Velasco, P.C.; Srebric, J.; Komarneni, S.; Berghage, R. Effects of plant and substrate selection on thermal performance of green roofs during the summer. Build. Environ. 2014, 78, 199-211. [CrossRef]

43. la Roche, P.; Berardi, U. Comfort and energy savings with active green roofs. Energy Build. 2014, 82, 492-504. [CrossRef] 
44. Managing energy costs in schools, A guide to energy conservation and savings for K-12 schools, Xcel Energy In. 2007. Available online: https://www.xcelenergy.com/staticfiles/xe/Marketing/Managing-Energy-CostsSchools.pdf (accessed on 12 December 2019).

45. Energy Efficiency in K-12 Schools \& State Applications; US Department of Energy: Washington, DC, USA, 2013.

46. Lemire, N. School and more. Ashrae J. 2010, 52, 34.

47. Ouf, M.M.; Mohamed, H.I. Energy consumption analysis of school buildings in Manitoba, Canada. Int. J. Sustain. Built Environ. 2017, 6, 359-371. [CrossRef]

48. Ouf, M. The effect of occupancy on school buildings' energy consumption in Manitoba. Ph.D. Dissertation, University of Manitoba, Winnipeg, MB, Canada, 2016.

49. U.S. DOE. Energyplus engineering reference. In The Reference to Energyplus Calculations; U.S. DOE: Washington, DC, USA; p. 2010.

50. Sailor, D.J. A green roof model for building energy simulation programs. Energy Build. 2008, 40, 1466-1478. [CrossRef]

51. Deru, M.; Field, K.; Studer, D.; Benne, K.; Griffith, B.; Torcellini, P.; Liu, B.; Halverson, M.; Winiarski, D.; Rosenberg, M.; et al. US Department of Energy Commercial Reference Building Models of the National Building Stock; National Renewable Energy Laboratory: Jefferson County, CO, USA, 2011; pp. 1-118.

52. U.S. DOE. Commercial Prototype Building Models, Department of Energy, United States. Available online: https://www.energycodes.gov/development/commercial/prototypemodels (accessed on 24 October 2019).

53. EnergyPlus. Energy Simulation Software. 2013. Available online: /https://www.energy.gov/eere/buildings/ energyplus (accessed on 23 September 2019).

54. Wilcox, S.; Marion, W. User's Manual for TMY3 Data Sets; National Renewable Energy Laboratory: Golden, CO, USA, 2008.

55. Logics, N. Canadian Weather for Energy Calculations; Users Manual and CD-ROM; Environment Canada: Downsview, ON, Canada, 1999.

56. Sailor, D.J.; Bass, B. Development and Features of the Green Roof Energy Calculator (GREC). J. Living Archit. 2014, 1, 36-58.

57. Feng, C.; Meng, Q.; Zhang, Y. Theoretical and experimental analysis of the energy balance of extensive green roofs. Energy Build. 2010, 42, 959-965. [CrossRef]

58. Gagliano, A.; Detommaso, M.; Nocera, F. Assessment of the Green Roofs Thermal Dynamic Behavior for Increasing the Building Energy Efficiencies. In Smart Energy Control Systems for Sustainable Buildings; Springer: Cham, Switzerland, 2017; pp. 37-59.

59. Nektarios, P.A.; Ntoulas, N.; Nydrioti, E.; Kokkinou, I.; Bali, E.M.; Amountzias, I. Drought stress response of Sedum sediforme grown in extensive green roof systems with different substrate types and depths. Sci. Hortic. 2015, 181, 52-61. [CrossRef]

60. Schaap, M.G.; van Genuchten, M.T. A modified Mualem-van Genuchten formulation for improved description of the hydraulic conductivity near saturation. Vadose Zone J. 2006, 5, 27-34. [CrossRef]

61. Mahmoodzadeh, M. Impact of Extensive Green Roofs on Energy Performance of School Buildings in four North American Climates. Masc Dissertation, University of Victoria, Victoria, BC, Canada, 2018.

62. Sailor, D.; Hutchinson, D.; Bokovoy, L. Thermal property measurements for ecoroof soils common in the western US. Energy Build. 2008, 40, 1246-1251. [CrossRef]

63. Green Roof Model (EcoRoof). Available online: https://bigladdersoftware.com/epx/docs/8-3/engineeringreference/green-roof-model-ecoroof.html (accessed on 12 December 2019).

64. Yaghoobian, N.; Srebric, J. Influence of plant coverage on the total green roof energy balance and building energy consumption. Energy Build. 2015, 103, 1-3. [CrossRef]

65. Zeng, C.; Bai, X.; Sun, L.; Zhang, Y.; Yuan, Y. Optimal parameters of green roofs in representative cities of four climate zones in China: A simulation study. Energy Build. 2017, 150, 118-131. [CrossRef]

66. Boafo, F.E.; Kim, J.-T.; Kim, J.-H. Evaluating the impact of green roof evapotranspiration on annual building energy performance. Int. J. Green Energy 2017, 14, 479-489. [CrossRef]

(C) 2019 by the authors. Licensee MDPI, Basel, Switzerland. This article is an open access article distributed under the terms and conditions of the Creative Commons Attribution (CC BY) license (http://creativecommons.org/licenses/by/4.0/). 